\title{
Substantiation of hemp seeds storage and processing technologies for functional, dietary and specialty products. Review
}

\author{
Mykola Oseyko', Nataliia Sova², Kristina Chornei ${ }^{2}$
}

\author{
1 - National University of Food Technologies, Kyiv, Ukraine \\ 2 - Dnipro State Agrarian and Economic University, Dnipro, Ukraine
}

Keywords:

Hemp

Seeds

Oil

Kernel

Flour

Functionality

Article history:

Received

29.01.2021

Received in

revised form

16.06.2021

Accepted

30.09.2021

\section{Corresponding \\ author:}

Nataliia Sova

E-mail:

sova.n.a@,

dsau.dp.ua

DOI:

$10.24263 / 2304-$ 974X-2021-10-3-

3

\section{Abstract}

Introduction. Analytical researches of the composition and quality of hemp seeds, their storage and processing methods and technologies for the production of functional, dietary and specialty products are presented.

Materials and methods. The subjects of research are aspects of the composition of industrial hemp seeds and its storing; peculiarities of production of hemp food products (oil, kernel, flour et al.); aspects of using hemp seeds and its derivative products. Research methods are the analysis of scientific works.

Results and discussion. Hemp seeds contain more than $30 \%$ of oil and about $25 \%$ of protein, a variety of minerals $(\mathrm{Ca}, \mathrm{Mg}, \mathrm{P}, \mathrm{K}, \mathrm{S}$, $\mathrm{Fe}, \mathrm{Zn}$, etc.), dietary fiber and biologically active substances. The component composition and biological value of hemp seeds depend upon the region and growing conditions. Sustainable storage conditions are seeds moisture content of $8-11 \%$, temperature of 14 $18{ }^{\circ} \mathrm{C}$ and relative humidity of $50-55 \%$. Products derived from processing of hemp seeds are oil, kernel, flour and protein concentrate. Oil is mainly extracted from seeds by mechanical pressing. Hemp oil contains fatty acids such as linoleic, linolenic and $\gamma$-linolenic acids, with the latter promoting the formation of $\gamma$-globulin, which has an important function in the human immune system. Hemp oil tocopherols act as antioxidants in alimentary, dietary and specialty products. Seed shelling machine did the hemp seeds de-hulling. The resulting product is rich in essential amino acids. Flour, fiber and protein concentrate are produced from hemp cake. Publications deal superficially with the relationship between the factors of material preparation, production process variables of hemp products, storage conditions and time in terms of the content of functional and biologically active components. Utilization of hemp seeds and their derivatives enhances the biological and nutritional value, functional and sensory properties of foods. Further research on the use of drugs to regulate the antimicrobial and antioxidant properties of functional, dietary and specialty products is of paramount importance.

Conclusion. The article substantiates the relevancy of using the presented theoretical, scientific and practical insights in integrated solutions for the processing of environmentally sound industrial and medical hemp seeds. 


\section{Introduction}

There is an increased interest of producers and consumers in products from industrial hemp seeds.

This requires increased scientific and practical knowledge and accelerated efforts in the systemic research into the integrated processing of seeds for the production of functional and specialty foods, dietary supplements and drugs.

\section{Materials and methods}

\section{Materials}

The subjects of research are:

- Aspects of the composition of industrial hemp seeds;

- Aspects of storing hemp seeds;

- Peculiarities of production of hemp food products (oil, kernel, flour, protein concentrates)

- Aspects of using hemp seeds and its derivative products.

\section{Methods}

Research methods are the analysis of scientific works.

\section{Results and discussion}

\section{Aspects of the composition of industrial hemp seeds}

Hemp seed (Figure 1) is a one-seeded fruit - a roundish egg-shaped nutlet consisting of an outer hard coat and a kernel located in the middle, surrounded by a thin film of dark green color. The seed has two cotyledons, a radicle and a budlet, which have grown together into a single whole - the embryo. The bulk of the nutrients in hemp seeds are concentrated in the embryo. Hemp seeds contain more than $30 \%$ of oil and about $25 \%$ of protein, as well as a fair amount of minerals, scarce coarse dietary fiber (cellulose, hemicellulose, pectin, and lignin) and biologically active substances (phospholipids, fatty acids, and vitamins). Hemp seeds mainly include edestin protein, as well as nitrogen-containing substances such as nucleic, choline and a small amount of trigonelline. In addition, 37 chemical elements are found in hemp seeds, of which calcium, magnesium, phosphorus, potassium, sulfur are dominant, as well as a small amount of iron and zinc (Sukhorada et al., 2009; Shewry et al., 2000; Yufriakova. et al., 2020). Shashkarov with co-authors (2016) additionally emphasizes the presence of rare earth elements in hemp seeds such as thorium, selenium, molybdenum, zirconium and beryllium. 


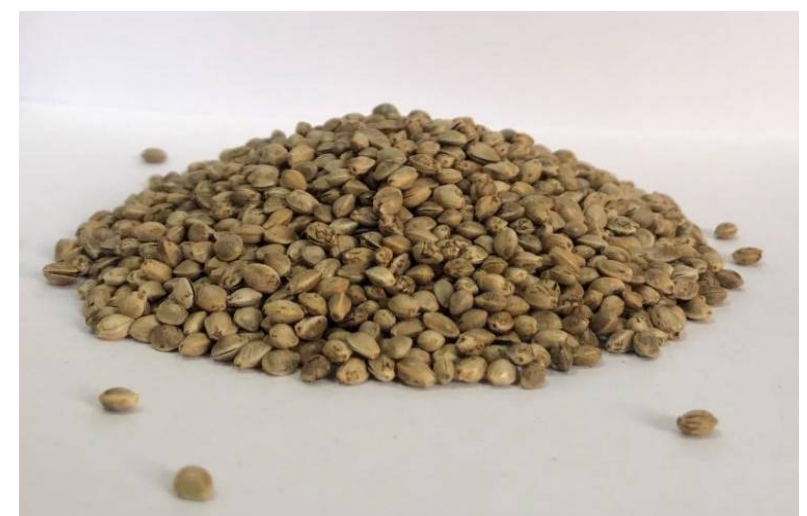

Figure 1. Hemp seeds

Comparison of the composition and quality indicators of hemp seeds from different parts of the world is shown in Table 1.

Composition and quality characteristics of hemp seeds

Table 1

\begin{tabular}{|l|l|c|c|c|c|}
\hline \multirow{2}{*}{ Component } & \multicolumn{4}{|c|}{ Content, \%, in hemp seeds of different region of production } \\
\cline { 2 - 6 } & $\begin{array}{l}\text { Pakistan } \\
\text { (Anwar et } \\
\text { al., 2006) }\end{array}$ & $\begin{array}{c}\text { Russia } \\
\text { (Serkov et } \\
\text { al., 2011) }\end{array}$ & $\begin{array}{c}\text { Canada } \\
\text { (Vonapartis } \\
\text { et al., 2015) }\end{array}$ & $\begin{array}{c}\text { Ukraine } \\
\text { (Oseyko et } \\
\text { al., 2019) }\end{array}$ & $\begin{array}{c}\text { USA } \\
\text { (Lan et } \\
\text { al., 2019) }\end{array}$ \\
\hline oil & $26.9-31.5$ & 30.24 & $26.9-30.6$ & $33.3 \pm 0.5$ & $24.3-28.1$ \\
\hline linoleic acid* & $56.5-60.5$ & 78.60 & 59.7 & $54.8-56.9$ & - \\
\hline$\alpha$-linolenic acid* & $16.9-20.0$ & 19.52 & 17.0 & $16.0-18.5$ & - \\
\hline protein & $23.0-26.5$ & 21.3 & $23.8-28.0$ & $22.5 \pm 0.15$ & $32.7-35.9$ \\
\hline fiber & $17.0-20.5$ & 17.71 & - & $32.3 \pm 0.2$ & - \\
\hline
\end{tabular}

* from the total amount of fatty acids.

As can be seen from Table 1,

- Ukraine has hemp seeds with the highest content of oil (33.3\%) (Oseyko et al., 2019), with the United States having the smallest (24.3-28.1\%) (Lan et al., 2019);

- United States have hemp seeds with the highest content of protein (32.7-35.9\%) (Lan et al., 2019), with Russia having the smallest (21.3\%) (Serkov et al., 2011);

- Ukraine has hemp seeds with the highest content of fiber (32.3\%) (Oseyko et al., 2019), with Russia having the smallest (17.71\%) (Serkov et al., 2011).

- The ash content in hemp seeds from different regions ranges from 5.0 to 7.6\% (Anwar et al., 2006; Serkov et al., 2011; Vonapartis et al., 2015; Lan et al., 2019).

Comparative analysis of the composition of mineral substances in hemp seeds from different parts of the world is shown in Tables 2 and 3. 
Content of macroelements in hemp seeds

\begin{tabular}{|c|c|c|c|}
\hline \multirow[b]{2}{*}{ Macroelement } & \multicolumn{3}{|c|}{ Content in hemp seeds of different region of production } \\
\hline & $\begin{array}{c}\text { Russia } \\
\text { (Serkov et al., 2011) }\end{array}$ & $\begin{array}{c}\text { Ukraine } \\
\text { (Oseyko et al., 2019) }\end{array}$ & $\begin{array}{c}\text { USA } \\
\text { (Lan et al., 2019) }\end{array}$ \\
\hline Phosphorus, g/kg & 1.11 & 8.9 & 4.1 \\
\hline Calcium, $\mathrm{g} / \mathrm{kg}$ & 0.28 & 0.9 & - \\
\hline Potassium, $\mathrm{mg} / \mathrm{kg}$ & 1.07 & - & - \\
\hline Magnesium, $\mathrm{g} / \mathrm{kg}$ & - & 2.4 & 3.4 \\
\hline
\end{tabular}

Content of microelements in hemp seeds

Table 3

\begin{tabular}{|l|c|c|c|}
\hline \multirow{2}{*}{ Microelement } & \multicolumn{3}{|c|}{ Content in hemp seeds of different region of production } \\
\cline { 2 - 4 } & $\begin{array}{c}\text { Romania } \\
\text { (Mihoc et al., } \\
\text { 2013) }\end{array}$ & $\begin{array}{c}\text { Ukraine } \\
\text { (Oseyko et al., } \\
\text { 2019) }\end{array}$ & $\begin{array}{c}\text { USA } \\
\text { (Lan et al., 2019) }\end{array}$ \\
\hline Iron, $\mathrm{mg} / \mathrm{kg}$ & $130-164$ & 74.7 & 46.7 \\
\hline Zinc, $\mathrm{mg} / \mathrm{kg}$ & $42-57$ & 56.1 & 28.2 \\
\hline Cobalt, $\mathrm{mg} / \mathrm{kg}$ & - & 0.5 & - \\
\hline Manganese, $\mathrm{mg} / \mathrm{kg}$ & $89-108$ & 59.4 & 169.1 \\
\hline Copper, $\mathrm{mg} / \mathrm{kg}$ & $10-12$ & - & 29.0 \\
\hline Nickel, $\mathrm{mg} / \mathrm{kg}$ & $1.6-6.1$ & - & 41.0 \\
\hline Chromium, $\mu \mathrm{g} / \mathrm{kg}$ & $598-877$ & - & - \\
\hline Molybdenum, $\mu \mathrm{gg} / \mathrm{kg}$ & $265-652$ & - & - \\
\hline Lead, $\mu \mathrm{g} / \mathrm{kg}$ & $217-626$ & - & - \\
\hline
\end{tabular}

As can be seen from Tables 2 and 3,

- Hemp seeds from Ukraine (Oseyko et al., 2019) and Russia (Serkov et al., 2011) were found to have the highest $(8.9 \mathrm{~g} / \mathrm{kg})$ and the lowest $(1.1 \mathrm{~g} / \mathrm{kg})$ phosphorus content, respectively;

- Hemp seeds from Romania (Mihoc et al., 2013) and USA (Lan et al., 2019) were found to have the highest (130-164 and $42-57 \mathrm{mg} / \mathrm{kg}$ ) and the lowest (46.7 and $28.2 \mathrm{mg} / \mathrm{kg}$ ) content of iron and zinc, respectively;

- Hemp seeds from the USA (Lan et al., 2019) and Ukraine (Oseyko et al., 2019) were found to have the highest $(169.1 \mathrm{mg} / \mathrm{kg})$ and the lowest $(59.4 \mathrm{~g} / \mathrm{kg})$ manganese content, respectively.

According to summarized data, the component composition and biological value of hemp seeds depend upon the region and growing conditions, and, obviously, on the seed material quality. Breders should pay due attention to the improvement of existing varieties of industrial hemp and development of new ones based on their primary and functional purpose. 


\section{Aspects of storing hemp seeds}

As hemp seeds are stored, their composition and quality characteristics change, which affects their further processing. Among the main parameters that affect the shelf life of hemp seeds are moisture content, temperature and storage time.

Klevtsov with co-authors (2015) determined the physical and mechanical properties of hemp seeds: 1000 kernel weight, bulk weight, moisture content, density of seeds, angle of repose, static and dynamic friction coefficients, flowability and intergrain space. This allows addressing practical issues. Physical and mechanical properties of hemp seeds were assessed based on the characteristics of grain masses. These properties have a bearing on the organization of seed harvesting and further processing of hemp seeds. Samples of hemp seeds of Ukrainian varieties Zolotonos'ki 15 and YuSO-31 had a bulk density ranging from 513 to $586 \mathrm{~kg} / \mathrm{m}^{3} ; 1000$ kernel weight of $15.2-17.7 \mathrm{~g}$; static internal friction coefficient of $0.47-$ 0.55; dynamic external friction coefficient of $0.30-0.52$; static external friction coefficient of 0.29-0.37. The data show that hemp seeds are extremely free flowing materials. The characteristics that determine the flowability of hemp seeds can be used to simulate their behavior as they move by gravity through sieves, containers, and the like.

Sacilik with co-authors (2003) proved that the higher moisture content of industrial hemp seeds correlates with the higher 1000 kernel weight, the angle of repose and the friction coefficient.

Sova with co-authors (2019) investigated the quality of industrial hemp seeds at the stages of post-harvest handling, namely: seeds from stems (sample 1), seeds from the bunker of a combine harvester (sample 2), seeds after primary cleaning on an OVS-25 grain cleaner (sample 3), seeds after drying on a stationary grain dryer (sample 4), and commercial seeds after sorting on the PETKUS K531 GIGANT grain cleaner (sample 5). Samples 4 and 5 had the moisture content not exceeded $11 \%$. The seed purity of the mechanically harvested sample 2 was less than that of the manually harvested sample 1 . The mass fraction of oil in samples 2 and 3 decreased in comparison with that of sample 1 . The increased acid value of oil in seed samples 2, 3, and 4 as opposed to sample 1 is attributed to the grain damage during their mechanical treatment. Following sorting, the acid value of oil in seeds decreased. Sample 1 was found to be the most resistant to oxidative deterioration during storage. Mechanized harvesting of hemp seeds requires stages of cleaning, sorting and wet seed conditioning. The identified imperfection of the drying process affected the increase in the peroxide value of oil. A decrease in the 1000 kernel weight was common for all post-harvest handling stages as opposed to sample 1 .

The method of harvesting hemp seeds was found to affect the change in its physical and chemical parameters. Thus, the water level indicator for manually harvested seeds (sample 1) was $2.5 \%$ less than for mechanically harvested seeds (sample 2). Mass fraction of oil in sample 1 was $0.7 \%$ more than that of sample 2 . Mechanized harvesting of hemp seeds was found to increase the acid and peroxide values of oil extracted from samples 1 and 2 by $0.22 \mathrm{mg} \mathrm{KOH} / \mathrm{g}$ and $0.651 / 2 \mathrm{O} \mathrm{mmol} / \mathrm{kg}$, respectively. Thus, harvesting and drying of hemp seeds deserve special attention (Sova et al., 2019).

Lukianenko with co-authors (2009) revealed the extent to which the main factors of drying hemp seeds (layer thickness, air flow rate, flow temperature and layer mixing) affected the process time and quality indicators of the product. The germination capacity and quality indicators of hemp seeds were most influenced by the air temperature above $60{ }^{\circ} \mathrm{C}$ in the drying zone.

According to (Small et al., 2012), hemp seeds of Canadian varieties were exposed to a combination of four temperature regimes $\left(20,5,-20\right.$ and $\left.-80^{\circ} \mathrm{C}\right)$ and three seed moisture 
indicators (11, 6 and 4\%) for 66 months. Storage of hemp seeds with a moisture content of $11 \%$ at $20^{\circ} \mathrm{C}$ was found to reduce the germination capacity to zero in less than 18 months. A decrease in temperature to $5{ }^{\circ} \mathrm{C}$ and moisture content to $6 \%$ had a positive effect on the survival of seeds. There has been no evidence of benefit from oxygen-free storage.

It was found in (Mishchenko, 2013) that the longer storage time of hemp seeds of Ukrainian varietiesresulted in the lower germination energy and capacity of seeds. Germination capacity showed a rather sharp decline after three years and was actually lost after four years under normal storage conditions.

Pariharwith co-authors (2014) investigated the effect of moisture, temperature and storage time on the germination capacity and survivability of hemp seeds released in India. The study was carried out with a combination of moisture content indicators $(5,7,8,10$ and $12 \%$ ), temperature indicators (environment, 15 and $-20^{\circ} \mathrm{C}$ ) and various storage periods $(0$, $3,6,9,12,18,24$ and 36 months). The critical moisture content was $5 \%$ and was found to increase to $7 \%$ at a storage temperature of $15{ }^{\circ} \mathrm{C}$, and to $12 \%$ at $-20{ }^{\circ} \mathrm{C}$. With a moisture content of 5 and $7 \%$, the survivability of hemp seeds was maintained for up to 36 months of storage, and with $8 \%$ up to 12 months of storage. A complete loss of survivability was reported after 24 months of storage of hemp seeds with a moisture content of $12 \%$, whereas a germination capacity decrease of more than $40 \%$ was observed after storage of hemp seeds for 36 months at $15^{\circ} \mathrm{C}$.

Suriyonga with co-authors (2015) revealed the effect of storage conditions on the quality of hemp seeds grown in Thailand. The hemp seeds were packed in aluminum foil and a polypropylene bag. Seeds packed in aluminum foil were stored at room temperature and at temperatures of 15,4 and $-4{ }^{\circ} \mathrm{C}$, and seeds in the polypropylene bag were stored at room temperature. The hemp seeds underwent a monthly quality control for 12 months. As a result, hemp variety, storage conditions and shelf life, and interactions between these parameters were found to influence seed quality. During storage, the moisture content of hemp seeds packed in the polypropylene bag varied with moisture control. Germination capacity and energy of seeds packed in both types of materials did not change for 6 months of storage at room temperature, with a germination energy decrease of 30\% observed during 8-12 months of storage. It should be noted that the germination energy of hemp seed samples stored at temperatures of 15,4 and $-4{ }^{\circ} \mathrm{C}$ for a year remained almost unchanged. Therefore, a temperature of $15^{\circ} \mathrm{C}$ (cold room) was suggested as the optimal storage condition for hemp seeds.

When stored, grain produces heat and moisture due to the vital activity (respiration) of grain mass (seeds, microorganisms, kernels, and impurities) and oxidation of organic substances. In addition, grains and seeds can absorb water vapor and gases from the environment. The degree of moisture absorption by the grain mass predetermines its hygroscopicity, which depends on the colloidal, physical, and structural properties of seeds (Oseiko, 2006).

Special attention should be given to the sorption properties of seeds when stored under various conditions, since it is the high oil content of oilseeds that makes their equilibrium moisture content significantly lower than that of grain crops. According to the research findings (Klevtsov, 2015), the most active moisture absorption was found to occur at a temperature of $25^{\circ} \mathrm{C}$ and a relative humidity of $80 \%$, with the lowest equilibrium moisture content recorded in seed samples at a temperature of $+5{ }^{\circ} \mathrm{C}$ and a relative humidity of $50 \%$. The equilibrium moisture content of hemp seeds is higher than that of flax seeds. As a result, hemp seeds can be stored in the relative humidity range of $50-80 \%$ until equilibrium moisture content is reached. Equilibrium moisture content was also found to increase with increasing storage temperature from 5 to $25^{\circ} \mathrm{C}$ within the same relative humidity. 
Hemp seeds of Ukrainian varieties are placed and stored in grain warehouses in accordance with applicable sanitary regulations and storage conditions. Transportation and storage of hemp seeds should take into account their conditions in terms of moisture and dockage. Reasonable conditions for storing hemp seeds for their subsequent complex processing are seeds moisture content of $8-11 \%$, temperature of $14-18{ }^{\circ} \mathrm{C}$ and relative humidity of $50-55 \%$. It is advisable that hemp seeds be stored in an anaerobic environment with minimal exposure to light (Oseyko et al., 2020).

Nataša with co-authors (2020) tested various chemical agents to obtain microbiologically safe industrial hemp seeds. Such seeds can be used for further use in various food technologies (with a reduced total microbial count, total yeast and mold counts). Reasonable storage conditions were different for different microorganisms. For hemp seeds produced in 2018, the room temperature storage was the most optimal. Storing seeds in hermetically sealed bags at refrigerator / freezer temperatures revealed a suppressed yeast and mold growth. For hemp seeds produced in 2019, storage in the refrigerator (to reduce the number of enterobacteria) and in the freezer (to reduce the total microbial count) were the reasonable storage conditions. For reduced total yeast and mold counts, room temperature storage was the reasonable storage conditions. Ethanol ( $75 \mathrm{vol} \%)$ was found to be the most effective disinfectant among the chemicals tested (ethanol, sodium bicarbonate, and sodium hypochlorite).

According to (Oseyko et al., 2020), the long-term storage of industrial hemp seeds of Ukrainian varieties was found to yield the moisture content ranging from 8.2 to $10.1 \%$, seed purity of $97.5-99.8 \%$, and seed oil content of $31.9-34.3 \%$. The decrease in the seed oil content observed from the second half of the storage period till the end can be attributed to the biochemical processes taking place in it throughout the long-term storage. That said, 1000 kernel weight ranged from 17.7 to $19.2 \mathrm{~g}$, with the bulk weight of the hemp seeds ranging from 503.8 to $530 \mathrm{~g} / 1$.

Summarizing the findings, researchers and producers should give special attention to the post-harvest handling conditions, as well as to the methods and conditions of storage of industrial hemp seeds for food purposes.

\section{Peculiarities of oil extraction from hemp seeds}

Mechanical pressing is the principal method for hemp oil extraction (Figure 2).

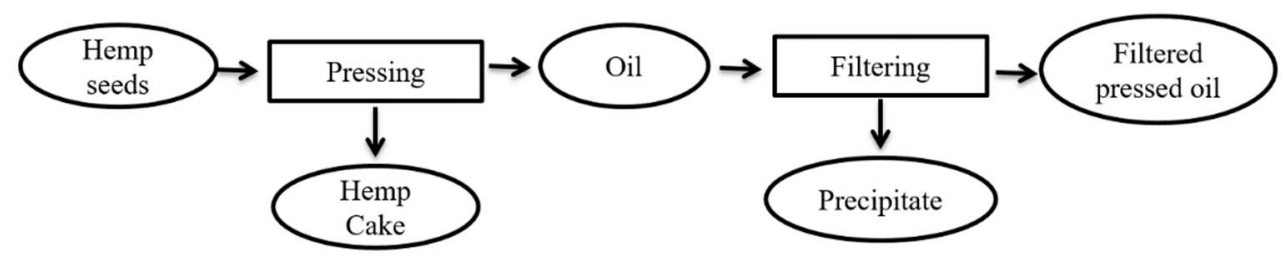

Figure 2. Cold-pressed hemp oil production scheme

Hemp oil is a rare source of nutrition through a unique $\omega-6 / \omega-3$ fatty acid ratio of $3: 1$ (Devi et al., 2019; Leizer et al., 2000). This is beneficial for the prevention and health of the cardiovascular, ophthalmic and other human body systems (Oseyko et al., 2020; Oseyko et al., 2019). This adds value to the production of highly refined hemp oil in the food industry and related industries (Devi et al., 2019). 
According to (Latif et al., 2009) the cold pressing of the material involved pretreatment of hemp seeds with enzyme preparations (Protex 7L, Viscozyme L, Kemzyme, Feedzyme, and Natuzyme). The oil content in the experimental samples (28.4-32.8\%) was higher than that in the test sample (26.7\%). According to the authors' data, the enzyme treatment was not affected by the content of protein, fiber and ash in seeds. No notable variations were found for the iodine value, refractive index, density and fatty acid composition of oil. The content of tocopherols in the experimental samples of hemp oil $(724.4-788.8 \mathrm{mg} / \mathrm{kg})$ was found to be higher than that in the test sample $(691.2 \mathrm{mg} / \mathrm{kg})$. When analyzing the research results, it was desirable to bring reasonable pressing temperature, dosing conditions for enzymes or mixtures of enzymes, as well as to refine additional technological operations.

Morar with co-authors (2010) determined the efficiency coefficient of cold pressing of hemp seeds (from 23.89 to $27.69 \%$ of resulting oil) with the oil content of the material from 30.89 to $33.25 \%$. The cold pressing process was also influenced by the quality of hemp seeds, which yielded reasonable values when using a pressing nozzle with a diameter of 8 and $10 \mathrm{~mm}$. The acid and peroxide values of hemp oil ranged from 0.65 to $4.45 \mathrm{mg} \mathrm{KOH} / \mathrm{g}$ of oil and from 0.62 to $26.91 \mathrm{mEq} \mathrm{O} / \mathrm{g}$, respectively. The authors recommend using the findings as a basis for further research and launching an information campaign to raise consumer awareness of the beneficial and therapeutic health effects of hemp oil.

Da Porto with co-authors (2012) applied an experimental design methodology to optimize the process of in-vitro extraction of oil from hemp seeds using supercritical carbon dioxide. The independent variables were operating temperature $\left(40,50\right.$ and $\left.60{ }^{\circ} \mathrm{C}\right)$, pressure $(250,300$ and 350 bar $)$ and particle size of the material $(0.59,0.71$ and $0.83 \mathrm{~mm})$. A second order polynomial equation was used to express oil yield and oxidation stability as a function of independent variables. The responses and variables were made consistent with each other using multiple regression equations. The maximum oil yield of $21.50 \%$ was obtained by extraction with supercritical carbon dioxide at a temperature of $40^{\circ} \mathrm{C}$, pressure of 300 bar and particle size of $0.71 \mathrm{~mm}$. The highest oil oxidation stability (2.35 Eq $\alpha$ toc/ml of oil) was obtained at a temperature of $60^{\circ} \mathrm{C}$, pressure of 250 bar and particle size of $0.83 \mathrm{~mm}$.

It was found in (Aladić et al., 2014) that a reasonable condition for obtaining an oil yield of $23.34 \%$ during cold pressing with subsequent extraction using supercritical $\mathrm{CO}_{2}$ was a temperature of $60{ }^{\circ} \mathrm{C}$, frequency of $20 \mathrm{~Hz}$, and a $6 \mathrm{~mm}$ diameter nozzle. Oil $(10.33 \%)$ was extracted from the press cake completely with supercritical $\mathrm{CO}_{2}$. According to the authors, oregano essential oil has served as the best antioxidant in protecting hemp oil from oxidative breakdown.

Aladić with co-authors (2015) compared the yield and composition of hemp oil extracted with supercritical $\mathrm{CO}_{2}$, n-hexane using a Soxhlet apparatus, and expeller pressing. Supercritical $\mathrm{CO}_{2}$ extraction yielded extracts with a higher tocopherol content. The amount of $\alpha$-tocopherol in supercritical extracts ranged from 37.09 to $110.61 \mathrm{mg} / \mathrm{kg}$, depending on the applied technological conditions. The content of $\gamma$-tocopherol was 2-3 times higher. The content of pigments in hemp oil obtained by extraction with supercritical $\mathrm{CO}_{2}$ ranged throughout the extraction process from 9.79 to $178.76 \mathrm{mg} / \mathrm{kg}$ of chlorophyll and from 8.15 to $57.66 \mathrm{mg} / \mathrm{kg}$ of carotene.

Devi with co-authors (2019) investigated various processes of hemp oil extraction (supercritical fluid extraction, Soxhlet, and ultrasonic treatment). Comparison was made in terms of economic assessment of an industrial scale, hemp oil yield and composition as well as physical and chemical properties of hemp oil. The maximum oil yield of $37.3 \%$ was obtained from material pretreated with ultrasound using the Soxhlet method.

Da Porto with co-authors (2015) described the pretreatment of hemp seeds without solvent exposure for 10, 20, and 40 minutes prior to oil extraction with supercritical $\mathrm{CO}_{2}$ at 
a temperature of $40{ }^{\circ} \mathrm{C}$, pressure of 300 bar, and $\mathrm{CO}_{2}$ consumption of $45 \mathrm{~kg} \mathrm{CO}_{2} / \mathrm{kg}$ of seeds. The maximum oil yield of $24.03 \%$ was obtained after a 10 -minute ultrasonic pretreatment.

According to (Crimaldi et al., 2017), a combination of a high pressing temperature $\left(70{ }^{\circ} \mathrm{C}\right)$ and a low screw speed $(22 \mathrm{rpm})$ was found to positively affect the oil yield for the Italian variety hemp seeds under experimental conditions when using pretreatment (heating for an hour at $50{ }^{\circ} \mathrm{C}$ ).

The authors in (Subratti et al., 2019) recommended using liquefied dimethyl ether as the most effective in a comparative study on the application of organic solvents in the extraction of hemp seed oil.

Esmaeilzadeh Kenari with co-authors (2020) established reasonable conditions for the use of solvent mixtures of hexane and isopropanol (0:100, 50:50, 100:0), extraction temperatures $\left(30,45\right.$ and $60{ }^{\circ} \mathrm{C}$ ) and sonication time (30,60 and $\left.90 \mathrm{~min}\right)$. Reasonable conditions were obtained at a hexane-to-isopropanol ratio of 60:40, a temperature of $40.26^{\circ} \mathrm{C}$, and a sonication time of 54.4 minutes.

Summarizing the studied data, scientists and manufacturers should place special emphasis on:

- The material pretreatment methods prior to oil extraction and their effect not only on the yield of the finished product, but also on its quality and safety performance;

- Conditions for obtaining hemp oil;

- Biological, ecological and economic efficiency of production.

\subsection{Peculiarities of the composition of hemp oils}

Hemp seed oil is distinguished not only by its decent taste, but also by its unique fatty acid profile and the content of associated biologically valuable substances. So, hemp oil contains fatty acids, five of which are polyunsaturated. Linoleic, linolenic and $\gamma$-linolenic fatty acids are the most biologically valuable. $\gamma$-linolenic acid promotes the formation of $\gamma$ globulin, which is instrumental in human immunity. In addition, hemp oil contains tocopherols (vitamin E), which act as antioxidants in both food and other foods. Hemp oil is known to have healing properties and is recommended for use in cataracts, glaucoma, diabetes mellitus, asthma, sclerosis, epilepsy, as well as for cancer prevention (Orhan et al., 2000; Virovets et al., 2014; Laiko Iet al., 2014).

Information on the fatty acid composition of oils obtained in various ways from hemp seeds found in different parts of the world is given in Table 4.

As can be seen from Table 4,

- Oil obtained from experimental varieties of Russian regions (Shelenga et al., 2010; Shelenga et al., 2012; Iurchenko et al., 2019) was found to have the highest $(17.4 \%)$ and the lowest $(7.5 \%)$ content of saturated fatty acids, in particular palmitic and stearic acids;

- Oil obtained from Ukrainian varieties (Oseyko et al., 2020) was found to have the highest (19.4\%) content of monounsaturated fatty acids, in particular oleic acid, with that from Russian varieties (Grigorev, 2019) having the lowest;

- Oil obtained from experimental varieties of Russian regions was found to have the highest $(96.4 \%)$ and the lowest (48.8\%) total content of polyunsaturated fatty acids, in particular linoleic, $\alpha$-linolenic, $\gamma$-linolenic and arachidonic acids;

- Oil obtained from Iranian varieties (Abdollahi et al., 2020) was found to have the highest $\omega$-6-to- $\omega-3$ ratio of 7.6:1, with that from Russian varieties (Iurchenko et al., 2019) having the lowest; 
Fatty acid composition of hemp oils

Table 4

\begin{tabular}{|c|c|c|c|c|c|c|c|c|}
\hline \multirow[b]{2}{*}{$\begin{array}{c}\text { Hemp oil } \\
\text { described in }\end{array}$} & \multicolumn{8}{|c|}{ Fatty acid content, $\%$} \\
\hline & 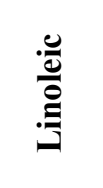 & 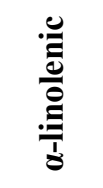 & $\frac{\frac{\pi}{0}}{0}$ & 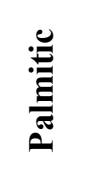 & 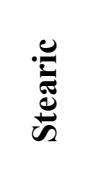 & 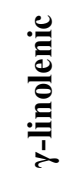 & 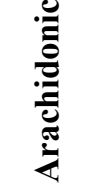 & $\omega-6: \omega-3$ \\
\hline Anwar et al., 2006 & $\begin{array}{c}56.5- \\
60.5\end{array}$ & $\begin{array}{l}16.8- \\
20.0\end{array}$ & $\begin{array}{c}10.2- \\
14.0\end{array}$ & $\begin{array}{l}5.7- \\
8.3\end{array}$ & $\begin{array}{l}2.2- \\
2.8\end{array}$ & $\begin{array}{c}0.6- \\
1.6\end{array}$ & - & $2.8: 1-3.2: 1$ \\
\hline $\begin{array}{l}\text { Shelenga et al., } \\
2010\end{array}$ & $\begin{array}{l}42.6- \\
57.4 \\
\end{array}$ & $\begin{array}{l}10.6- \\
22.3 \\
\end{array}$ & $\begin{array}{l}8.9- \\
15.0 \\
\end{array}$ & $\begin{array}{l}6.6- \\
14.3 \\
\end{array}$ & $\begin{array}{c}1.7- \\
3.1 \\
\end{array}$ & $\begin{array}{l}1.4- \\
7.8 \\
\end{array}$ & $\begin{array}{c}0.3- \\
2.1 \\
\end{array}$ & $2.4: 1-4.6: 1$ \\
\hline Serkov et al., 2011 & $\begin{array}{c}58.4- \\
59.1\end{array}$ & $\begin{array}{l}19.5- \\
20.1\end{array}$ & $\begin{array}{c}12.1- \\
12.8\end{array}$ & - & - & - & - & $2.9: 1-3: 1$ \\
\hline $\begin{array}{l}\text { Vyrovets et al., } \\
2011\end{array}$ & $\begin{array}{c}36.0- \\
57.0\end{array}$ & $\begin{array}{c}12.0- \\
19.0\end{array}$ & $\begin{array}{c}11.9- \\
18.8\end{array}$ & $\begin{array}{c}5.8- \\
9.9\end{array}$ & $\begin{array}{c}2.5- \\
3.5\end{array}$ & $\begin{array}{c}0.7- \\
3.8 \\
\end{array}$ & $\begin{array}{c}0.1- \\
1.1\end{array}$ & $2.5: 1-2.8: 1$ \\
\hline $\begin{array}{l}\text { Da Porto et al., } \\
2012\end{array}$ & 59.6 & 18.0 & - & - & - & 3.4 & - & $2.8: 1$ \\
\hline $\begin{array}{l}\text { Shelenga et al., } \\
2012\end{array}$ & $\begin{array}{l}42.6- \\
57.4 \\
\end{array}$ & $\begin{array}{l}10.6- \\
22.3 \\
\end{array}$ & $\begin{array}{l}8.9- \\
15.7\end{array}$ & $\begin{array}{l}6.6- \\
14.3 \\
\end{array}$ & $\begin{array}{c}1.7- \\
3.1 \\
\end{array}$ & $\begin{array}{c}1.4- \\
7.8\end{array}$ & $\begin{array}{c}0.1- \\
2.6 \\
\end{array}$ & 2.6:1-3.1:1 \\
\hline $\begin{array}{l}\text { Montserrat-de la } \\
\text { Paz et al., } 2014\end{array}$ & 55.0 & 16.0 & 11.0 & - & - & - & - & $3.4: 1$ \\
\hline $\begin{array}{l}\text { Shashkarov et al., } \\
2016\end{array}$ & $\begin{array}{c}50.0- \\
70.0 \\
\end{array}$ & $\begin{array}{l}15.0- \\
25.0 \\
\end{array}$ & - & - & - & - & - & $2.8: 1-3.3: 1$ \\
\hline $\begin{array}{l}\text { Mikulcova et al., } \\
2017\end{array}$ & $\begin{array}{l}55.3- \\
57.3 \\
\end{array}$ & $\begin{array}{l}16.7- \\
20.3 \\
\end{array}$ & $\begin{array}{l}9.0- \\
12.1 \\
\end{array}$ & $\begin{array}{c}5.9- \\
6.2 \\
\end{array}$ & $\begin{array}{c}2.2- \\
2.4 \\
\end{array}$ & $\begin{array}{c}3.0- \\
4.4 \\
\end{array}$ & $\begin{array}{c}1.0- \\
1.7 \\
\end{array}$ & $2.8: 1$ \\
\hline Sova et al., 2018 & $\begin{array}{c}54.8- \\
55.0\end{array}$ & $\begin{array}{c}14.6- \\
14.8\end{array}$ & $\begin{array}{c}16.1- \\
16.2\end{array}$ & 6.0 & $\begin{array}{l}3.0- \\
3.1\end{array}$ & 2.3 & 1.0 & $3.6: 1$ \\
\hline $\begin{array}{l}\text { Baibekov et al., } \\
2019\end{array}$ & 55.8 & $\begin{array}{l}15.2- \\
17.8 \\
\end{array}$ & $\begin{array}{c}13.4- \\
13.5 \\
\end{array}$ & $\begin{array}{l}5.8- \\
10.7 \\
\end{array}$ & $\begin{array}{c}2.6- \\
2.8 \\
\end{array}$ & - & - & $3.1: 1-3.8: 1$ \\
\hline $\begin{array}{l}\text { Iurchenko et al., } \\
2019\end{array}$ & $\begin{array}{l}36.0- \\
50.0 \\
\end{array}$ & $\begin{array}{l}15.0- \\
28.0 \\
\end{array}$ & $\begin{array}{l}6.0- \\
16.0 \\
\end{array}$ & $\begin{array}{c}5.8- \\
9.9 \\
\end{array}$ & $\begin{array}{c}1.7- \\
5.6 \\
\end{array}$ & - & - & $1.8: 1-2.9: 1$ \\
\hline Grigorev, 2019 & $\begin{array}{c}53.4- \\
64.2 \\
\end{array}$ & $\begin{array}{l}12.6- \\
27.1\end{array}$ & $\begin{array}{l}5.9- \\
14.0\end{array}$ & - & - & $\begin{array}{c}0.6- \\
5.1 \\
\end{array}$ & - & $2: 1-4: 1$ \\
\hline Oseyko, 2019 & $\begin{array}{l}54.8- \\
56.9 \\
\end{array}$ & $\begin{array}{l}16.0- \\
18.5 \\
\end{array}$ & $\begin{array}{c}13.3- \\
13.6 \\
\end{array}$ & $\begin{array}{c}5.7- \\
6.3 \\
\end{array}$ & $\begin{array}{c}3.0- \\
3.2 \\
\end{array}$ & $\begin{array}{l}1.3- \\
2.8 \\
\end{array}$ & $\begin{array}{c}0.8- \\
2.4 \\
\end{array}$ & $3: 1-3.7: 1$ \\
\hline $\begin{array}{l}\text { Abdollahi et al., } \\
2020\end{array}$ & $\begin{array}{l}57.5- \\
64.0 \\
\end{array}$ & $\begin{array}{l}7.6- \\
22.9 \\
\end{array}$ & - & - & - & - & - & $2.8: 1-7.6: 1$ \\
\hline Serkov et al., 2020 & 57.0 & 16.0 & 12.0 & - & - & 3.3 & - & $3: 1$ \\
\hline $\begin{array}{l}\text { Oseyko et al., } \\
2020\end{array}$ & $\begin{array}{c}53.4- \\
56.6 \\
\end{array}$ & $\begin{array}{c}11.3- \\
16.2 \\
\end{array}$ & $\begin{array}{c}14.9- \\
19.4 \\
\end{array}$ & $\begin{array}{c}5.6- \\
6.6 \\
\end{array}$ & $\begin{array}{c}3.3- \\
3.5 \\
\end{array}$ & $\begin{array}{l}1.6- \\
2.6 \\
\end{array}$ & - & $3.4: 1-5: 1$ \\
\hline
\end{tabular}


Comparative characteristics of the tocopherol content in hemp oils from different parts of the world are given in Table 5 .

Table 5

Comparative characteristics of the tocopherol content in hemp oils

\begin{tabular}{|l|c|c|c|c|}
\hline \multirow{2}{*}{\multicolumn{1}{|c|}{ Hemp oil described in }} & \multicolumn{4}{c|}{ Tocopherol content, mg/kg } \\
\cline { 2 - 5 } & $\boldsymbol{\alpha}-$ & $\boldsymbol{\delta}-$ & $\boldsymbol{\gamma}-$ & $\boldsymbol{\beta}$ - \\
\hline Anwar et al., 2006 & $54.0-60.4$ & $35.0-45.6$ & $600.0-745.0$ & - \\
\hline Vonapartis et al., 2015 & - & 7.74 & 24.81 & - \\
\hline Kriese et al., 2005 & $18 \pm 0.5$ & $12 \pm 0.4$ & $217 \pm 3.2$ & $2 \pm 0.04$ \\
\hline Montserrat-de la Paz et al., 2014 & $73.4 \pm 2.86$ & - & - & - \\
\hline Oseyko et al., 2019 & $234.0-246.2$ & $12.8-14.0$ & $316.0-322.0$ \\
\hline
\end{tabular}

As can be seen from Table 5,

- Oil samples from Pakistan (Anwar et al., 2006) and Canada (Vonapartis et al., 2015) were found to have the highest $(745 \mathrm{mg} / \mathrm{kg})$ and the lowest $(24.81 \mathrm{mg} / \mathrm{kg}) \gamma$-tocopherol content, respectively;

- Oil samples from Ukraine (Oseyko et al., 2019) and Germany (Kriese et al., 2005) were found to have the highest $(246.2 \mathrm{mg} / \mathrm{kg})$ and the lowest $(18 \mathrm{mg} / \mathrm{kg}) \alpha$-tocopherol content, respectively;

- Oil samples from Pakistan (Anwar et al., 2006) and Canada (Vonapartis et al., 2015) were found to have the highest $(45.6 \mathrm{mg} / \mathrm{kg})$ and the lowest $(7.74 \mathrm{mg} / \mathrm{kg}) \delta$-tocopherol content, respectively.

Summarizing the data of section 3.1, it should be noted that the reviewed publications give insufficient attention to the relationship between the factors of material treatment, parameters of hemp oil production, conditions of hemp oil purification and long-term storage in terms of the content of fatty acids and tocopherols.

\subsection{Oxidation stability of hemp oil during storage}

Thanks to its high content of $\omega-6$ and $\omega-3$ fatty acids and minor biologically active components with antioxidant activity, hemp oil is now generally recognized by consumers as health-promoting. Although tocopherols, polyphenols, and phytosterols prevent the oxidative degradation of hemp oils, high levels of chlorophyll can adversely affect the quality of oil (Liang et al., 2015).

Sapino and co-authors (2005) provided a comparison of hemp oils and olive oil in terms of some physicochemical quality indicators and oxidation stability assessment. The peroxide value of hemp oil (1998 and 1999 samples) was 1.57 and $5.151 / 2 \mathrm{O} \mathrm{mmol} / \mathrm{kg}$. Hemp oil was less resistant to peroxidation than olive oil. Chlorophyll found in extra virgin olive oil had a higher photostability than that found in hemp seed oil, possibly due to higher antioxidant content in olive oil. Hemp oil was found to contain a certain amount of vitamin E ( 0.08 and $0.25 \mathrm{mg} / \mathrm{l})$.

According to Abuzaytoun with co-authors (2006), the oxidative stability of flax oil and hemp oil, as well as their compositions devoid of minor components, were evaluated in the dark at $60{ }^{\circ} \mathrm{C}$ and under fluorescent light at $27^{\circ} \mathrm{C}$. According to the authors, the biologically active constituents of these edible oils are instrumental in their oxidative stability. However, 
their stability is contributed by the composition of phenolic antioxidants and total tocopherols in oil, as well as the type of pigments. Untreated flax oil and hemp oil compositions showed higher stability. In addition, non-fibrous hemp oil had a higher oxidative stability than untreated flax oil. This was evidenced by the purification of the 1,1-diphenyl-2picrylhydrazyl radical and the data on total phenols.

Raikos with co-authors (2015) investigated the effect of heating, storage and light exposure on the oxidative stability of the dispersed phase of the emulsion - hemp oil. The lipid oxidation rate increased following heat treatment and exposure to light, while oxidation markers remained relatively unchanged during storage of the emulsion at $4{ }^{\circ} \mathrm{C}$ for 10 days. The induction period of the emulsions was reduced to $26 \%$. The concentration of substances reacting with thiobarbituric acid increased 4.5 times, depending on the processing conditions.

It was found in (Lamotkin et al., 2016) that during the determination of resistance of the composition of rape oil and hemp oils to oxidation by air oxygen (64:36) with a $\omega$-6-to$\omega-3$ ratio of 10:1, after 5 days of bubbling, the acid, peroxide and anisidine values of the composition were $2.99 \mathrm{mg} \mathrm{KOH} / \mathrm{g}, 22.62 \mathrm{mmol}(\mathrm{SO}) / \mathrm{kg}$ and $2.98 \mathrm{U} / \mathrm{g}$, respectively. Based on the findings, the authors concluded that the composition of rape oil and hemp oils is not stable during storage.

In (Liang et al., 2018), ultrasonic treatment of cold-pressed hemp oil combined with bleaching clays (sepiolite, activated bentonite and industrial clay) proves very effective in reducing chlorophyll content from 56.3 to $14.8,9.9$ and $7.8 \mu \mathrm{g} / \mathrm{kg}$, respectively. The method is not only rapid and clean but requires significantly less bleaching clay. Hemp oil treated in this way exhibits greater oxidative stability making it more attractive for industrial and consumer use. The results of ultrasonic bleaching suggest its potential for prolonging the shelf-life of oil. According to the authors, utilizing the ultrasonic bleaching technique as an alternative to conventional bleaching would be beneficial to the edible oil industry.

Hamidioglul with co-authors (2019) investigated the stability of hemp oil using natural plant extracts such as rosemary, pomegranate, and green tea, together with vitamin $\mathrm{E}$. The concentration of each plant extract was $30 \mathrm{mg} / \mathrm{l}$ and $50 \mathrm{mg} / \mathrm{l}$. Vitamin $\mathrm{E}$ was mixed with oil in an amount of $2 \mathrm{~g} / \mathrm{l}$. The value of the induction period of oil with additional plant extracts was significantly higher than that of the test samples. The vitamin E oil sample exhibited the longest induction period $\left(4.12 \pm 0.04\right.$ hours at $\left.120^{\circ} \mathrm{C}\right)$ during the Rancimat test. The authors attribute this to the strong antioxidant ability of the tocopherol content in vitamin E. The induction period of the hemp oil sample with added extracts in the amount of $30 \mathrm{mg} / \mathrm{L}$ was $3.56 \pm 0.06$ hours for pomegranate, $3.67 \pm 0.05$ hours for green tea, $3.69 \pm 0.03$ hours for rosemary; in the amount of $50 \mathrm{mg} / \mathrm{L}$ : $3.6 \pm 0.03$ hours for pomegranate, $3.7 \pm 0.01$ hours for green tea, $3.89 \pm 0.02$ hours for rosemary. Herbal extracts and vitamin $E$ had a positive effect on the peroxide value of hemp oil as opposed to the test sample. The peroxide value of the test sample was $19.4 \pm 0.12 \mathrm{mEq} / \mathrm{kg}$, of the sample with added vitamin E $12.14 \pm 0.17 \mathrm{mEq} / \mathrm{kg}$, with added extracts in the amount of $30 \mathrm{mg} / \mathrm{l}: 14.43 \pm 0.06 \mathrm{mEq} / \mathrm{kg}$ for rosemary, $15.23 \pm 0.05 \mathrm{mEq} / \mathrm{kg}$ for green tea, $16.1 \pm 0.09 \mathrm{mEq} / \mathrm{kg}$ for pomegranate; in the amount of $50 \mathrm{mg} / \mathrm{l}: 13.12 \pm 0.17 \mathrm{mEq} / \mathrm{kg}$ for rosemary, $14.55 \pm 0.08 \mathrm{mEq} / \mathrm{kg}$ for green tea, $15.76 \pm 0.13 \mathrm{mEq} / \mathrm{kg}$ for pomegranate.

Moczkowska with co-authors (2020) characterized the effectiveness of antioxidants of rosemary extract obtained using various solvents (ethanol, methanol, acetone, and ethyl acetate) on the quality of hemp oil and its storage stability. The effectiveness of antioxidants was compared with hydroxytoluene butyl ether. Rosemary methanolic and ethyl acetate extracts showed the highest and lowest total phenols and antioxidant capacity, respectively. The lowest value of reaction substances with thiobarbituric acid following 14 days of storage was established for the rosemary methanolic and acetone extracts, 1.01 and $1.18 \mu \mathrm{mol} / \mathrm{kg}$, 
respectively. Utilization of rosemary extract indicates a greater antioxidant effect on certain fatty acids, such as $\alpha$-linoleic acid, compared to the reference. According to the authors, rosemary extract can provide a natural alternative to synthetic antioxidants.

According to (Babiker et al., 2021), reasonable heat treatment of hemp seeds (14 min at $160^{\circ} \mathrm{C}$ ) brought about an increase in phenolic acids, polyphenols, and glycosylated flavonoids. Roasting of seeds had little effect on the fatty acid content. The amount of phosphorus and magnesium in hemp seeds dropped significantly, but the amount of calcium, iron, copper, manganese and zinc increased over time of roasting.

Summarizing the studied data, scientists and manufacturers should place significant emphasis on:

- The utilization of plant extracts as antioxidants instead of synthetic ones;

- The conditions for obtaining and storing hemp oil in order to stabilize the composition and quality indicators.

\section{Peculiarities of production of hemp food products}

\subsection{Aspects of obtaining a hemp kernel}

Petrachenko with co-authors (2019) characterized one of the promising directions of processing non-narcotic hemp seeds - obtaining a hulled seed kernel. Profound insight into structures of mechanisms for hulling with different operation principle allowed determining the peculiarities, pros and cons of the single-blow and multiple-blow techniques. The effect of the shape of the working body (impeller or disk) of the hulling mechanism on the ability to destroy the seed coat has been clarified. The oriented single-blow technique, which is implemented in the design of a centrifugal dehuller, was found to be more effective in terms of dehulling hemp seeds. The impeller of a closed sectoral type has been found to have the prospect of further utilization and requires in-depth research.

The hemp kernel production scheme is shown in Figure 3.

Prior to the hemp kernel production, hemp seeds are tested for purity and moisture. Industrial hemp seeds are loaded into a dehulling system, where the fruit coat is destroyed and the kernel is released. The resulting mixture, which consists of a ready-made hemp kernel, semi-crushed and whole industrial hemp seeds, coats and chaff, is divided into fractions. The hemp kernel yield ranges from 33.2 to $41.4 \%$, chaff - from 0.6 to $5.2 \%$, substandard seeds from 1.3 to $4.8 \%$, intermediate products - from 53.3 to $61.2 \%$ (Oseyko et al., 2020).

Some manufacturers split the mixture in two stages. The first stage provides for separation into 4 fractions on a sieve cleaner: coats (waste following the air part of the separator); whole and semi-crushed seeds - rejects from the upper sieve; ready kernel rejects from the lower sieve; chaff - outsiftings from the lower sieve. After that, the ready kernel ends up in another air cleaner that yields two fractions - ready kernel and chaff. The waste products of this technology are coats and two chaff alternatives. 


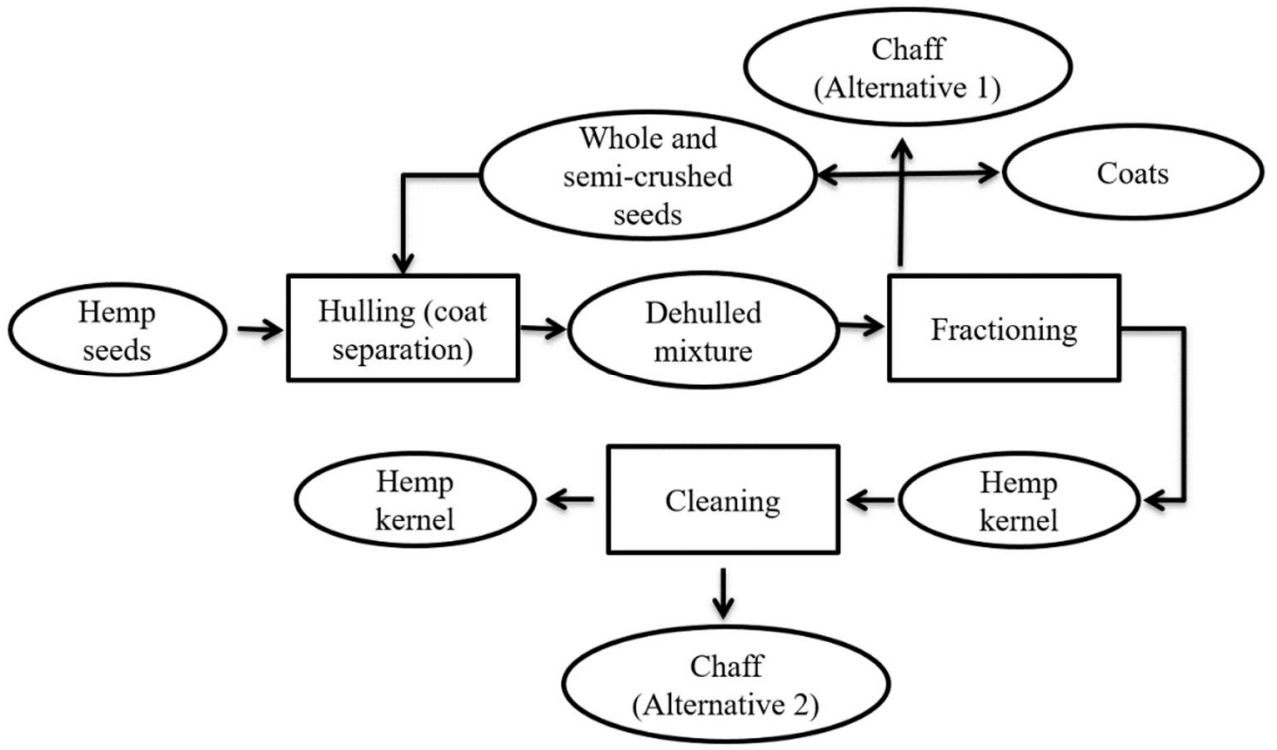

Figure 3. Hemp kernel production scheme

Physicochemical indicators of quality and amino acid composition of hemp kernel in comparison with the raw material input are given in Tables 6 and 7 (Oseyko et al., 2019).

Physicochemical indicators of quality of hemp kernel (Oseyko M. et al., 2019)

\begin{tabular}{|c|c|c|c|}
\hline \multirow{3}{*}{ Component } & \multicolumn{3}{|c|}{ Content } \\
\hline & \multicolumn{2}{|c|}{ Hemp seed findings } & \multirow{2}{*}{$\begin{array}{l}\text { "Hemp- } \\
\text { Flax"** }\end{array}$} \\
\hline & Hulled & Whole & \\
\hline Moisture content, $\%$ & $7.0 \pm 0.02$ & $8.4 \pm 0.02$ & $\leq 7.0$ \\
\hline Mass fraction of impurities, $\%$ & $0.4 \pm 0.02$ & $3.3 \pm 0.15$ & - \\
\hline Acid value, $\mathrm{mg} \mathrm{KOH} / \mathrm{g}$ & $3.1 \pm 0.1$ & $3.3 \pm 0.1$ & - \\
\hline Mass fraction of oil, ${ }^{*} \%$ & $54.0 \pm 1$ & $33.3 \pm 0.5$ & 48.0 \\
\hline Mass fraction of protein, ${ }^{*} \%$ & $32.8 \pm 0.2$ & $22.5 \pm 0.15$ & 34.0 \\
\hline Mass fraction of fiber $* \%$ & $5.5 \pm 0.03$ & $32.3 \pm 0.2$ & 6.0 \\
\hline Mass fraction of ash, ${ }^{*} \%$ & $6.5 \pm 0.03$ & $5.91 \pm 0.03$ & - \\
\hline Mass fraction of minerals ${ }^{*}$ : & & & \\
\hline Phosphorus, g/kg & 13.5 & 8.9 & 13.8 \\
\hline Calcium, g/kg & 0.5 & 0.9 & 0.4 \\
\hline Magnesium, $\mathrm{g} / \mathrm{kg}$ & 2.7 & 2.4 & 5.6 \\
\hline Iron, $\mathrm{mg} / \mathrm{kg}$ & 94.1 & 74.7 & 76.0 \\
\hline Zinc, $\mathrm{mg} / \mathrm{kg}$ & 111.8 & 56.1 & 85.0 \\
\hline Cobalt, $\mathrm{mg} / \mathrm{kg}$ & 1.0 & 0.5 & - \\
\hline Manganese, $\mathrm{mg} / \mathrm{kg}$ & 38.3 & 59.4 & 57.0 \\
\hline Copper, $\mathrm{mg} / \mathrm{kg}$ & 12.6 & not determined & 9.0 \\
\hline
\end{tabular}

Note: ${ }^{*}$ - on a dry basis; ${ }^{* *}$ - organization specialized in processing hemp and flax in the Netherlands and Romania. 
Table 6 shows the improved performance of the hemp kernel compared to the whole seed. The content of oil and protein can be seen to have increased by 1.5 times, and the content of macro- and microelements (except for calcium and manganese) can be seen to have increased by 1.5 times for phosphorus, 1.25 times for iron and 2 times for zinc and cobalt.

Amino acid composition of hemp kernel (Oseyko M. et al., 2019)

Table 7

\begin{tabular}{|c|c|c|c|c|c|c|c|}
\hline \multirow{3}{*}{ Amino acid } & \multirow{3}{*}{$\begin{array}{c}\text { "n" or } \\
\text { "e"e" }\end{array}$} & \multicolumn{6}{|c|}{ Content } \\
\hline & & \multicolumn{2}{|c|}{ Hemp kernel } & \multicolumn{2}{|c|}{$\begin{array}{c}\text { Whole hemp } \\
\text { seeds }\end{array}$} & \multicolumn{2}{|c|}{ "Hemp-flax" } \\
\hline & & $\mathrm{mg} / 100 \mathrm{~g}$ & $\%$ & $\mathrm{mg} / 100 \mathrm{~g}$ & $\%$ & $\mathrm{mg} / 100 \mathrm{~g}$ & $\%$ \\
\hline Alanine & "n" & 1624 & 5.4 & 642 & 5.5 & 1760 & 5.6 \\
\hline Arginine & "n" & 4149 & 13.7 & 1409 & 12.1 & 3420 & 11.0 \\
\hline Aspartic acid & "n” & 2616 & 8.6 & 1100 & 9.4 & 1870 & 5.9 \\
\hline Valine & "e" & 946 & 3.1 & 351 & 3.0 & 1880 & 6.0 \\
\hline Histidine & "n" & 936 & 3.1 & 326 & 2.8 & 860 & 2.8 \\
\hline Glycine & "n" & 1546 & 5.1 & 644 & 5.5 & 1420 & 4.6 \\
\hline Glutamic acid & "n" & 5546 & 18.4 & 2370 & 20.4 & 6340 & 20.3 \\
\hline Isoleucine & "e" & 833 & 2.8 & 323 & 2.8 & 1320 & 4.2 \\
\hline Leucine & "e" & 2023 & 6.7 & 791 & 6.8 & 2000 & 6.4 \\
\hline Lysine & "e" & 1538 & 5.1 & 661 & 5.7 & 960 & 3.1 \\
\hline Methionine & "e" & 877 & 2.9 & 263 & 2.3 & 770 & 2.4 \\
\hline Proline & "n" & 1410 & 4.7 & 593 & 5.1 & - & - \\
\hline Serine & "n" & 1888 & 6.2 & 656 & 5.6 & 1850 & 5.9 \\
\hline Tyrosine & "n" & 1200 & 4.0 & 383 & 3.3 & 1670 & 5.4 \\
\hline Threonine & "e" & 1091 & 3.6 & 438 & 3.8 & 1580 & 5.1 \\
\hline Tryptophan & "e" & & not de & rmined & & 210 & 0.7 \\
\hline Phenylalanine & "e" & 1396 & 4.6 & 525 & 4.5 & 1740 & 5.6 \\
\hline Cysteine & "n" & 604 & 2.0 & 163 & 1.4 & 1570 & 5.0 \\
\hline Total & & 30223 & 100 & 11638 & 100 & 31220 & 100 \\
\hline
\end{tabular}

Note: " $\mathrm{n}$ " is nonessential amino acid; "e" is essential amino acid.

Table 7 shows that the hemp kernel in Ukrainian variety seeds is rich in essential amino acids. The content of isoleucine, leucine, lysine, methionine, threonine, phenylalanine in the hemp kernel significantly exceeds that in the whole hemp seeds. The hemp kernel is found to have an increased content of lysine, which is usually deficient. Additional processing of hemp seeds to produce flour or protein concentrate can significantly improve data on increasing the biological value of products. In particular, thanks to additional processing, the protein content in hemp flour on adry basis can be as high as $44.0 \%$ and in protein concentrate $-52.1-75 \%$ (Oseyko et al., 2019).

Almost all Ukrainian businesses use hemp kernel waste as bedding in animal husbandry, and some in the production of fuel briquettes or pellets. But, in our opinion, it is unacceptable to incinerate or dispose of hemp kernel waste (as intermediate products). Table 8 shows the composition of intermediate products derived from the production of hemp kernel, on a dry basis (Sova. et al., 2021). 
Characterization of the composition of intermediate products derived from the production of hemp kernel (Sova et al., 2021)

Table 8

\begin{tabular}{|l|c|c|c|}
\hline \multirow{2}{*}{ Component } & \multicolumn{3}{|c|}{ Content, \% } \\
\cline { 2 - 4 } & Coats & $\begin{array}{c}\text { Chaff } \\
\text { (Alternative 1) }\end{array}$ & $\begin{array}{c}\text { Chaff } \\
\text { (Alternative 2) }\end{array}$ \\
\hline moisture & $7.90 \pm 0.02$ & $12.00 \pm 0.02$ & $8.84 \pm 0.02$ \\
\hline protein & $10.75 \pm 0.15$ & $26.90 \pm 0.2$ & $26.90 \pm 0.2$ \\
\hline oil & $7.81 \pm 0.2$ & $41.23 \pm 0.5$ & $39.13 \pm 0.5$ \\
\hline fiber & $60.23 \pm 0.5$ & $22.20 \pm 0.2$ & $32.45 \pm 0.2$ \\
\hline
\end{tabular}

Table 8 shows that both chaff alternatives are rich in protein $(26.9 \pm 0.2 \%)$ and oil $(39.13 \pm 0.5 \%$ and $41.23 \pm 0.5 \%)$. Although seed coats have significantly lower content of protein and oil, they have been found to be rich in fiber $(60.23 \pm 0.5 \%)$.

The mineral composition of intermediate products derived from the production of hemp kernel, on a dry basis, is given in Table 9 (Sova et al., 2021).

Table 9

Mineral content of intermediate products derived from the production of hemp kernel (Sova et al., 2021)

\begin{tabular}{|l|c|c|c|}
\hline \multirow{2}{*}{\multicolumn{1}{c|}{ Mineral }} & \multicolumn{3}{c|}{ Content } \\
\cline { 2 - 4 } & Coats & $\begin{array}{c}\text { Chaff } \\
\text { (Alternative 1) }\end{array}$ & $\begin{array}{c}\text { Chaff } \\
\text { (Alternative 2) }\end{array}$ \\
\hline Calcium, g/kg & 2.10 & 1.72 & 2.06 \\
\hline Phosphorus, g/kg & 2.37 & 13.00 & 12.72 \\
\hline Magnesium, g/kg & 1.13 & 4.40 & 4.91 \\
\hline Iron, $\mathrm{mg} / \mathrm{kg}$ & 138.39 & 147.97 & 195.45 \\
\hline Zinc, $\mathrm{mg} / \mathrm{kg}$ & 20.52 & 98.31 & 102.23 \\
\hline Copper, $\mathrm{mg} / \mathrm{kg}$ & 13.31 & 14.79 & 15.36 \\
\hline Manganese, $\mathrm{mg} / \mathrm{kg}$ & 99.54 & 137.13 & 185.28 \\
\hline
\end{tabular}

It can be seen from data in Table 9 that intermediate products derived from the production of hemp kernel contain significant amounts of minerals. However, the content of phosphorus, magnesium, iron, zinc and manganese differs significantly, with seed coats containing less of them in comparison with chaffs.

Further research should expediently be devoted to the utilization of intermediate products derived from the production of hemp kernel in the technology of functional food products, dietary supplements, and feed products (Sova et al., 2021).

Shen and co-authors (2020) revealed that the use of hemp kernel in the hemp protein isolate production technology increased the yield and quality of the isolate (purity, Arginine vs Lysine ratio, color). Utilization of hemp kernel as a raw material input does not affect protein composition and structure. 


\subsection{Aspects of hemp flour and protein (protein concentrate) production}

Hemp meal contains $30-35 \%$ of protein, more than $10 \%$ of oil and $25 \%$ of fiber. $100 \mathrm{~g}$ of hemp cake corresponds to 73 feed units. Phytin (phytic acid calcium magnesium salt), being a major component of hemp cake, sees heavy medical use in stimulating hematopoiesis, enhancing growth and development of bone tissue, as well as in managing some diseases of the nervous system (Shashkarov et al., 2016).

Hemp cake is a unique source of protein, natural carotene, phytosterols and phospholipids, which are helpful in preventing anemia, with $\mathrm{K}, \mathrm{Zn}, \mathrm{S}$ and $\mathrm{Mg}$ strengthening the heart muscle and nervous system. Hemp cake contains fiber, which is essential for the normal functioning of the gastrointestinal tract; improves motor skills, eliminates toxins from the body; positively affects the respiratory system; enhances treatment of cardiovascular diseases and obesity; improves kidney and liver function. Hemp cake is unique in that it contains adequate amounts of complete protein. Bulk hemp products such as flour, fiber and protein concentrate are produced by crushing the cake and fractioning the resulting mass. The resulting fractions have a different size, with the smallest one, commonly referred to as "hemp protein", having the highest protein content. This fraction also contains considerable amounts of fat, ash and fiber. A production scheme of hemp flour, "protein" and fiber is shown in Figure 4.

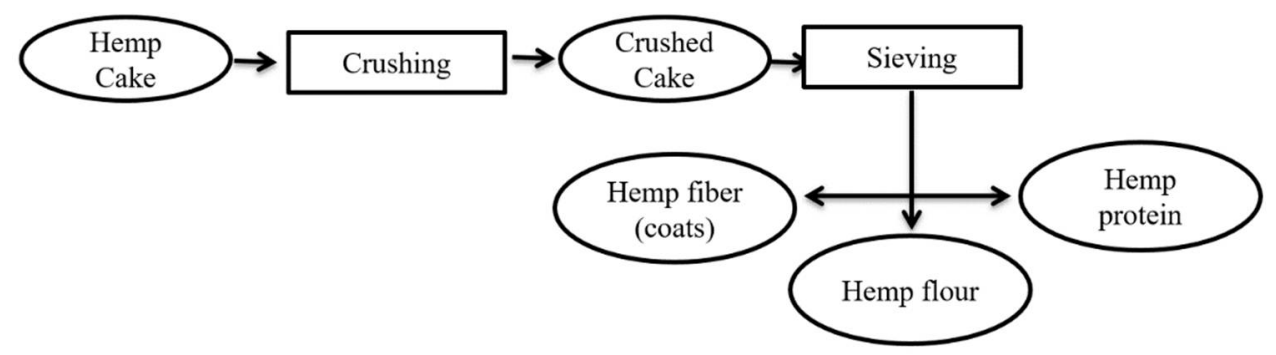

Figure 4. Bulk hemp products production scheme

Physicochemical indicators of quality and amino acid composition of bulk hemp products are given in Tables 10 and 11 (Sova et al., 2018).

Table 10

Physicochemical indicators of quality of bulk hemp products (Sova et al., 2018)

\begin{tabular}{|l|c|c|c|c|}
\hline \multirow{2}{*}{ Component } & \multicolumn{4}{|c|}{ Content, \%, in } \\
\cline { 2 - 5 } & Hemp seeds & "Protein" & Flour & Fiber \\
\hline moisture content, \% & 8.36 & 7.00 & 6.50 & 7.17 \\
\hline protein & 24.70 & 52.14 & 44.01 & 22.65 \\
\hline oil* & 33.62 & 15.68 & 11.65 & 10.62 \\
\hline ash* & 4.99 & 9.55 & 8.84 & 5.05 \\
\hline fiber* & 36.85 & 5.51 & 13.88 & 44.94 \\
\hline pest contamination & \multicolumn{4}{|l}{} \\
* on a dry basis & N/D \\
\hline
\end{tabular}


According to data in Table 10, the hemp "protein" fraction is rich in protein, oil, minerals, which makes it the most valuable for consumption among the presented bulk hemp products. The biological value of hemp "protein" is $81.7 \%$ (Sova et al., 2018).

Table 11

Amino acid composition of bulk hemp products, mg/100 g (Sova et al., 2018)

\begin{tabular}{|l|c|c|c|c|}
\hline \multicolumn{1}{|c|}{ Amino acid } & Hemp seeds & "Protein" & Flour & Fiber \\
\hline Alanine & 735 & 1556 & 1462 & 671 \\
\hline Arginine & 1647 & 3589 & 3411 & 1336 \\
\hline Aspartic acid & 1359 & 2263 & 2224 & 1286 \\
\hline Valine & 445 & 885 & 910 & 371 \\
\hline Histidine & 413 & 870 & 806 & 335 \\
\hline Glycine & 740 & 1272 & 1319 & 717 \\
\hline Glutamic acid & 2870 & 4445 & 4625 & 2593 \\
\hline Isoleucine & 374 & 782 & 813 & 331 \\
\hline Leucine & 913 & 1951 & 1877 & 813 \\
\hline Lysine & 788 & 1458 & 1300 & 843 \\
\hline Methionine & 302 & 686 & 630 & 184 \\
\hline Proline & 673 & 1358 & 1305 & 604 \\
\hline Serine & 824 & 1597 & 1514 & 725 \\
\hline Tyrosine & 469 & 1078 & 955 & 376 \\
\hline Threonine & 555 & 1056 & 1029 & 485 \\
\hline Phenylalanine & 653 & 1350 & 1271 & 570 \\
\hline Cysteine & 197 & 594 & 545 & 160 \\
\hline
\end{tabular}

Pojić with co-authors (2014) showed how the value of hemp seed flour can be increased. Chemically, two fractions that contained cotyledons $(>180$ and $<180 \mu \mathrm{m})$ had a notably higher content of protein $(41.2 \pm 0.04 \%$ and $44.4 \pm 0.02 \%$, respectively), lipids $(15.1 \pm 0.02 \%$ and $18.6 \pm 0.04 \%$, respectively), and carbohydrates $(4.96 \pm 0.11 \%$ and $3.46 \pm 0.08 \%$, respectively) than fractions that contained coats $(>350$ and $>250 \mu \mathrm{m})$, which, in turn, had a higher content of crude fiber $(29.5 \pm 0.04 \%$ and $21.3 \pm 0.03 \%$, respectively). All fractions were found to have balanced $\omega-6 / \omega-3$ fatty acids (3:1). Antinutrients (trypsin inhibitors, phytic acid, glucosinolates and condensed tannins) are mainly located in the cotyledon fractions. The data obtained by the authors show that fractioning of hemp seed flour can be useful in concentrating valuable target compounds. Therefore, this facilitates their extraction.

\subsection{Aspects of production of hemp protein concentrates and isolates}

Hemp seeds contain a broad spectrum of biologically active chemical compounds. In particular, increasingly greater attention is given to proteins and biologically active peptides as an alternative source of nutraceuticals. Hemp seeds contain the salt-soluble globulins or edestin $(\sim 75 \%)$ and the water-soluble albumin $(\sim 25 \%)$ as the main storage proteins. Hemp seed proteins have a high level of arginine and a sulfur-rich protein fraction, two unique 
features that impart high nutritional values. Hemp protein has antioxidant and antiinflammatory properties. It is a by-product of hemp oil technology (Stefan et al., 2018).

Hemp protein hydrolysates generated by enzymatic hydrolysis are composed of polypeptides, oligopeptides, and free amino acids displaying high availability of biological activity. Hemp protein hydrolysates have showed different biological activities as antihypertensive, hypocholesterolemic, antioxidant, antithrombotic, and immunomodulatory effects (Zanoni et al., 2017). Hemp protein is a complete protein source containing all essential amino acids. Plant-based sources of protein are often considered inferior to animalbased ones, but hemp protein is an exception. It contains all 9 essential amino acids found in other complete protein sources such as meat or dairy products. Hemp protein is also classified as a source of high-quality protein comparable to that of soybean or egg white (Fountoulakis et al., 2008). (James et al., 2010) notes that lysine is the first limiting amino acid in hemp protein. Removing seed coats improves lysine digestibility.

Wang with co-authors (2018) suggested that hemp seed protein isolates have a higher nutritional value in terms of amino acid composition and are easier to digest than soy protein isolate. They can be used as the primary source of proteins in human nutrition.

Yin with co-authors (2009) revealed the effects of succinylation and acetylation on some functional, structural properties and trypsin digestibility of hemp protein isolate. Succinylation leads to gradual increase in hemp protein solubility from 30 to $85-90 \%$, while in the acetylation case, the protein solubility is improved only at low anhydride levels, increasing from 30 to about 50\%. Differential scanning calorimetry and intrinsic fluorescence spectrum analysis indicated gradual structural unfolding of proteins, or exposure of hydrophobic clusters to the solvent, especially at higher anhydride levels. Additionally, trypsin digestibility was significantly improved by the succinylation. The results indicated that succinylation could be applied to modify some selected functional properties of hemp proteins.

Malomo with co-authors (2014) identified the effects of $\mathrm{pH}$ and protein concentration on some structural and functional properties of hemp seed protein isolate $(84.15 \%$ protein content) and defatted hemp seed flour (44.32\% protein content). The protein isolate was characterized by a minimum protein solubility at $\mathrm{pH} 4.0$, which increased as $\mathrm{pH}$ decreased or increased. In contrast, the hemp seed flour had minimum protein solubility at $\mathrm{pH} 3.0$, which increased at higher $\mathrm{pH}$ values. Intrinsic fluorescence and circular dichroism data indicated that the hemp protein isolates had a well-defined structure at $\mathrm{pH} 3.0$, which was lost as $\mathrm{pH}$ value increased. The differences in structural conformation of hemp protein isolates at different $\mathrm{pH}$ values were reflected as better foaming capacity at $\mathrm{pH} 3.0$ when compared to $\mathrm{pH}$ 5.0, 7.0, and 9.0. Therefore, the functional properties of hemp seed protein products are dependent upon structural conformations as well as protein content and $\mathrm{pH}$.

In (Teh et al., 2016), hemp protein isolates were hydrolyzed using proteases (AFP, HT, ProG, actinidin, and zingibain). Physical properties of hydrolysates were evaluated by particle size, zeta potential and surface hydrophobicity. HT protease had the highest rate of caseinolytic activity at the lowest concentration, $0.1 \mathrm{mg} / \mathrm{ml}$, compared to other proteases that required concentration of $100 \mathrm{mg} / \mathrm{ml}$ to achieve their maximum rate of caseinolytic activity. This led to the highest degree of hydrolysis of hemp protein isolate as affected by HT protease in the SDS-PAGE profiles. Among all proteases and substrates, HT resulted in the highest biological activity generated from alkali extracted hemp protein isolate in the shortest time ( 2 hours) compared to the other protease preparations.

In (Girgih et al., 2013), hemp seed protein hydrolysate was produced through simulated gastrointestinal tract digestion of hemp protein isolate, followed by partial purification and separation into eight peptide fractions. The peptide fractions exhibited higher oxygen radical 
absorbance capacity as well as scavenging of 2,2-diphenyl-1-picrylhydrazyl, superoxide and hydroxyl radicals when compared to hemp seed protein hydrolysate. Radical scavenging activities of the fractionated peptides increased as content of hydrophobic amino acids or elution time was increased, with the exception of hydroxyl radical scavenging that showed decreased trend. Although glutathione, hemp seed protein hydrolysate and peptide fractions possessed low ferric ion reducing ability, all of them had strong $(>60 \%)$ metal chelating activities. Inhibition of linoleic acid oxidation using some of the hemp seed protein hydrolysate peptide fractions was higher at $1 \mathrm{mg} / \mathrm{ml}$ when compared to that observed at $0.1 \mathrm{mg} / \mathrm{ml}$ peptide concentration. Peptide separation resulted in higher concentration of some hydrophobic amino acids (especially proline, leucine and isoleucine) in the fractions when compared to hemp seed protein hydrolysate.

It was found in (Mamone et al., 2019) that hemp-based food products were considered less allergenic than those based on other edible seeds. High purity grade hemp flour and hemp protein isolate were derived from defatted hemp cakes, residues of hemp oil extract. The resulting hemp protein isolate contained almost $86 \%$ protein, represented mainly by the storage protein edestin (which accounted for $70 \%$ of the total protein). In vitro hemp protein digestibility was determined using a static model of gastrointestinal digestion. Hemp flour and hemp protein isolate showed a high degree of digestibility. The survival of potential biologically active and/or allergenic peptide sequences in digests was investigated by peptidomic analysis. Only a limited number of sequences survived gastrointestinal digestion. All known hemp allergens, including the major thaumatin-like protein, were entirely eliminated by the hemp protein isolate production process. These data support the use of hemp protein isolate as an ingredient for hypoallergenic foods.

According to (Potin et al., 2020), hemp seeds were found to contain considerable amounts of nutrients in the hemp kernel and in its derivative products $26 \%$ of protein and $36 \%$ of oil, respectively. The authors presented the current state of knowledge about the hemp kernel in terms of its composition, nutritional value, extraction, physicochemical, functional and biological properties. Various extraction methods have been proposed to extract major hemp protein fractions from the hemp cake. The protein obtained from hemp flour is classified as globulins and albumins and contains highly digestible (about $90 \%$ ) essential amino acids. The authors emphasize that hemp protein hydrolysates have a wide range of health-promoting biological activities, such as antioxidant properties, metal chelation, antihypertensive, hypoglycemic properties, etc.

Raikos with co-authors (2015) investigated the effect of heat treatments on the denaturation and oxidative stability of hemp seed protein during simulated gastrointestinal digestion. Heat-denatured hemp protein isolate solutions were prepared by heating hemp protein isolate $(2 \mathrm{mg} / \mathrm{ml}, \mathrm{pH} 6.8)$ to $40,60,80$ and $100{ }^{\circ} \mathrm{C}$ for $10 \mathrm{~min}$. Heat-induced denaturation of the protein isolates was monitored by polyacrylamide gel electrophoresis. Heating hemp protein isolate at temperatures above $80^{\circ} \mathrm{C}$ significantly reduced solubility and led to the formation of large protein aggregates. Additionally, the oxidative stability of the resulting peptides was investigated. Heating did not significantly affect the formation of oxidation products. The results suggest that heat treatments should ideally unfold below $80{ }^{\circ} \mathrm{C}$ in order to preserve heat stability and solubility of hemp protein isolate.

In (Pojić et al., 2014), hemp proteins have been found to form high-quality emulsions similar to those of milk-based emulsions. A novel hemp protein concentrate has been shown to have $>70 \%$ solubility at $\mathrm{pH} 4.0-6.0$, whereas most plant proteins are typically insoluble. Addition of hemp protein to diet led to reduced pathological intensity of renal disease and cardiovascular diseases. Moreover, hemp seed enzymatic hydrolysates exhibited antioxidant 
and antihypertensive properties. According to the authors, hemp proteins and hydrolysates have the potential to be used as ingredients to formulate functional foods.

Dapčević-Hadnađev with co-authors (2020) identified the ability of hemp protein to act as a functional agent in a variety of foods. The role of hemp protein as an emulsifier, foaming, film-forming and gelling agent creates the potential for replacing synthetic agents with natural ones. Studies have revealed a biological functionality of hemp proteins, i.e. application of enzymatic hydrolysis for the production of biologically active peptides.

Summarizing information in section 4 , it should be noted that the reviewed publications deal superficially with the relationship between the factors of material preparation, production process variables of hemp foods, storage conditions and time in terms of the content of functional and biologically active components.

\section{Aspects of using hemp seeds and its derivative products}

Foods containing hemp seeds and oil are currently marketed worldwide for both animal and human nutrition. It was estimated that the global market for hemp consists of more than 25,000 products (Cerino et al., 2020). Hemp seeds are widely used in the production of kernel, oil, flour, protein, milk, animal feed, etc. (Serkov et al., 2011; Pojić et al., 2014; Karus et al., 2004; Leson, 2006; Kolodziejczyk et al., 2012; Cherney et al., 2016; Fike, 2016; Schluttenhofer et al., 2017; Klir et al., 2019; Williams, 2019; Leonard et al., 2020; Xu et al., 2020; Della Rocca et al., 2020; Crini et al., 2020; Farinon et al., 2020). Hemp seeds or their ingredients are added to beverages, for example, in the brewing and wine industry, as well as to neutral products (Cerino et al., 2020). In Latvia (Ivanovs et al., 2017), for example, crushed hemp seeds see heavy use in the manufacture of butter-based delicacy paste. Hemp oil is used for cosmetics and personal care items, paints, printing inks, detergents and solvents. In addition to food products, hemp flour is used in animal and poultry husbandry (Silversides et al., 2005). Hemp seeds and their derivative products have been scientifically proven to have a curative, health-improving and rehabilitative effect on the human body (Noelia et al., 2019; Metwally et al., 2021; Valizadehderakhshan et al., 2021).

Table 12 shows example uses of hemp seeds and their derivative products in technologies of functional, dietary and specialty products.

Summarizing the data in Table 12, the following should be noted:

- Utilization of hemp seeds and their derivatives in various food technologies enhances the biological and nutritional value, functional and sensory properties of finished products;

- Adding hemp derivative products to the formulation of baked goods increases their shelf life;

- Utilization of hemp derivative products in bakery technologies ensures decreased amounts of gluten in finished products, which is relevant in modern conditions. 
Utilization of hemp seeds and their derivative products as a functional component

\begin{tabular}{|c|c|c|c|}
\hline $\begin{array}{l}\text { Product or } \\
\text { semi- } \\
\text { finished } \\
\text { product }\end{array}$ & $\begin{array}{l}\text { Hemp } \\
\text { supplement } \\
\text { content }\end{array}$ & Efficiency & Reference \\
\hline $\begin{array}{l}\text { Mixed rye- } \\
\text { wheat bread }\end{array}$ & $\begin{array}{l}10 \% \text { of wheat } \\
\text { flour replaced } \\
\text { with hemp flour }\end{array}$ & $\begin{array}{l}\text { Fermentation property increased by } \\
42 \% \text {, specific volume by } 26.3 \% \text { and } \\
\text { finished product porosity by } 10.9 \% \text {. } \\
\text { Dough, proofing and baking time } \\
\text { reduced by } 30 \% \text {. } 150 \mathrm{~g} \text { of this product } \\
\text { meets the daily requirement for } \\
\text { polyunsaturated fatty acids. }\end{array}$ & $\begin{array}{c}\text { Samofalova et } \\
\text { al., } 2004\end{array}$ \\
\hline $\begin{array}{l}\text { Wheat } \\
\text { bread }\end{array}$ & $\begin{array}{l}\text { Hemp/wheat } \\
\text { flour ratio } 10 / 90\end{array}$ & $\begin{array}{l}\text { Increased nutritional value. Increased } \\
\text { content of proteins, macro- and } \\
\text { microelements, especially iron. } \\
\text { Decreased gluten content. }\end{array}$ & $\begin{array}{l}\text { Pojić M. et } \\
\text { al., } 2015\end{array}$ \\
\hline $\begin{array}{l}\text { Wheat } \\
\text { bread }\end{array}$ & $\begin{array}{l}15 \% \text { of hemp } \\
\text { flour, } 4 \% \text { of } \\
\text { hemp kernel } \\
\text { and } 8 \% \text { of } \\
\text { hemp oil }\end{array}$ & $\begin{array}{l}\text { Increased content of proteins, essential } \\
\text { fatty acids, dietary fiber. Decreased } \\
\text { gluten content. Increased shelf life of } \\
\text { bread. }\end{array}$ & $\begin{array}{l}\text { Bădărău } \\
\text { Carmen et al., } \\
2018\end{array}$ \\
\hline $\begin{array}{l}\text { Wheat } \\
\text { bread }\end{array}$ & $\begin{array}{l}50 \% \text { of hemp } \\
\text { flour }\end{array}$ & $\begin{array}{l}\text { Increased protein content (13.38- } \\
19.29 \mathrm{~g} / 100 \mathrm{~g}) \text {. Change in the hardness } \\
\text { of bread crust due to a decrease in bread } \\
\text { stability index from } 1.12 \text { to } 0.05 \text {. } \\
\text { Increase in crumb browning index from } \\
29.69 \text { to } 46.26 \text {. Increase in total } \\
\text { polyphenols from } 256.43 \text { to } 673.59 \mathrm{mg} \\
\text { GAE/kg. Formation of furan derivatives } \\
\text { (furfuryl alcohol, furfuryl aldehyde, } \\
\text { hydroxymethylfurfural). }\end{array}$ & $\begin{array}{l}\text { Mikulec et al., } \\
\quad 2019\end{array}$ \\
\hline $\begin{array}{l}\text { Wheat } \\
\text { bread }\end{array}$ & $\begin{array}{l}10 \% \text { of hemp } \\
\text { flour }\end{array}$ & $\begin{array}{l}\text { Intensification of dough maturation. } \\
\text { Production time reduced by } 8-20 \\
\text { minutes. Reduced calorie content due to } \\
\text { low starch content. Product } \\
\text { consumption compensates the daily } \\
\text { requirement of the human body for } \\
\text { proteins by } 9.5 \% \text {, fats by } 5.5 \% \text {, fiber by } \\
13.6 \% \text {, } \omega-3 \text { and } \omega-6 \text { fatty acids by } 37 \\
\text { and } 29 \% \text { respectively. Increased } \\
\text { content of B vitamins and minerals } \\
\text { (phosphorus, magnesium, calcium, } \\
\text { iron). }\end{array}$ & $\begin{array}{l}\text { Falendysh et } \\
\text { al., } 2019\end{array}$ \\
\hline $\begin{array}{l}\text { Wheat } \\
\text { bread and } \\
\text { bakery } \\
\text { products }\end{array}$ & $\begin{array}{l}10 \% \text { of hemp } \\
\text { kernel or } 5 \% \text { of } \\
\text { hemp protein }\end{array}$ & $\begin{array}{l}\text { Reduced baking, convexity losses of } \\
\text { baked goods. Increased nutritional } \\
\text { value of the finished product. }\end{array}$ & $\begin{array}{l}\text { Ruban et al., } \\
\quad 2016\end{array}$ \\
\hline $\begin{array}{l}\text { Gluten-free } \\
\text { bread }\end{array}$ & $\begin{array}{l}20 \% \text { of hemp } \\
\text { protein }\end{array}$ & $\begin{array}{l}\text { Increase in fiber levels from } 15.2 \text { to } \\
61.0 \mathrm{~g} / \mathrm{kg} \text { and dietary fiber from } 29.3 \text { to } \\
90.0 \mathrm{~g} / \mathrm{kg} \text {. Increase in bread volume }\end{array}$ & $\begin{array}{l}\text { Korus et al., } \\
2017\end{array}$ \\
\hline
\end{tabular}




\begin{tabular}{|c|c|c|c|}
\hline & $\begin{array}{l}\text { concentrate and } \\
\text { flour }\end{array}$ & $\begin{array}{l}\text { from } 633 \text { to } 878 \mathrm{ml} \text { Improved } \\
\text { organoleptic characteristics (color and } \\
\text { taste). Limited product staling through } \\
\text { reduced rate of amylopectin } \\
\text { recrystallization during storage. }\end{array}$ & \\
\hline $\begin{array}{l}\text { Gluten-free } \\
\text { bread }\end{array}$ & $\begin{array}{l}\text { Non- } \\
\text { conventional } \\
\text { starter culture } \\
\text { using hemp, } \\
\text { chia and quinoa } \\
\text { flour }\end{array}$ & $\begin{array}{l}\text { Reduced } \mathrm{pH} \text {, specific volume and } \\
\text { staling rate of the finished product. } \\
\text { Increased bread porosity. }\end{array}$ & $\begin{array}{c}\text { Jagelaviciute } \\
\text { et al., } 2021\end{array}$ \\
\hline $\begin{array}{l}\text { Whole- } \\
\text { wheat bread }\end{array}$ & $\begin{array}{l}5,7,10 \% \text { of } \\
\text { hemp flour }\end{array}$ & $\begin{array}{l}\text { Product crumb and crust browning. } \\
\text { More uniform crumb structure. } \\
\text { Providing the finished product with a } \\
\text { light nutty aroma and pleasing savor. } \\
\text { Protein content increased by } 4-4.4 \% \text {. } \\
\text { Content of natural food sorbents in the } \\
\text { product increased by } 17.2 \% \text {. Reduced } \\
\text { bread brittleness. Soft product for } 24- \\
48 \text { hours. }\end{array}$ & $\begin{array}{l}\text { Bazhai- } \\
\text { Zhezherun et } \\
\text { al., } 2020\end{array}$ \\
\hline $\begin{array}{l}\text { Bread } \\
\text { sticks }\end{array}$ & $\begin{array}{l}15 \% \text { hemp cake } \\
\text { flour }\end{array}$ & $\begin{array}{l}\text { Water absorption capacity of the } \\
\text { resulting bake mix increased by } 6 \% \text {. } \\
\text { Dough balls running increased by } 7.4 \% \text {. } \\
\text { Carbon dioxide generation during } \\
\text { dough fermentation }(180 \text { min) reduced } \\
\text { by } 16 \% \text {. Titratable acidity increased by } \\
16 \% \text {. }\end{array}$ & $\begin{array}{l}\text { Iorgacheva et } \\
\text { al., } 2020\end{array}$ \\
\hline Pasta & $\begin{array}{l}5 \% \text { of semolina } \\
\text { flour replaced } \\
\text { with hemp flour }\end{array}$ & $\begin{array}{l}\text { Increased protein, fat and crude fiber } \\
\text { content. Improved functional properties } \\
\text { (antioxidant activity, increased content } \\
\text { of macro-, microelements and phenolic } \\
\text { compounds). Consistent cooking } \\
\text { performance of pasta. Reduced cooking } \\
\text { time, product surface stickiness. }\end{array}$ & $\begin{array}{l}\text { Pojić et al., } \\
2014\end{array}$ \\
\hline $\begin{array}{l}\text { Gluten-free } \\
\text { crackers }\end{array}$ & $\begin{array}{l}20 \% \text { of hemp } \\
\text { flour }\end{array}$ & $\begin{array}{l}\text { Enriched with minerals, fiber (39- } \\
249 \%) \text { and polyunsaturated fatty acids. } \\
\text { Decreased carbohydrate content }(8.4- \\
42.3 \%) \text {. Increased antioxidant } \\
\text { properties. }\end{array}$ & $\begin{array}{l}\text { Radočaj et al., } \\
2014\end{array}$ \\
\hline $\begin{array}{l}\text { Gluten-free } \\
\text { sugar } \\
\text { cookies }\end{array}$ & $\begin{array}{l}\text { Hemp/cornmeal } \\
\text { ratio } 80: 20\end{array}$ & $\begin{array}{l}\text { Improved organoleptic properties } \\
\text { (texture and physicochemical } \\
\text { properties). }\end{array}$ & $\begin{array}{l}\text { Lukin et al., } \\
\quad 2017\end{array}$ \\
\hline $\begin{array}{l}\text { Shortbread } \\
\text { cookies }\end{array}$ & $\begin{array}{l}20 \% \text { of hemp } \\
\text { cake }\end{array}$ & $\begin{array}{l}\text { Increased cookie strength and porosity, } \\
\text { moisture content increased by } 0.5- \\
0.8 \% \text {, wetness index by } 10-15 \% \text {. } \\
\text { Enriched with complete protein, } \\
\text { chlorophyll, vitamins and minerals. } \\
\text { Developed cookies have functional } \\
\text { properties. } 100 \mathrm{~g} \text { of cookies covers the } \\
\text { daily human need for dietary fiber by } \\
11-16 \% \text {. }\end{array}$ & $\begin{array}{l}\text { Holia et al., } \\
2018\end{array}$ \\
\hline
\end{tabular}




\begin{tabular}{|c|l|l|c|}
\hline Cookies & $\begin{array}{l}20 \% \text { of hemp } \\
\text { flour (raw and } \\
\text { roasted) }\end{array}$ & $\begin{array}{l}\text { Increased percentage of protein, oil, } \\
\text { ash, phenols and antioxidant activity. } \\
\text { Decreased hardness of products. }\end{array}$ & $\begin{array}{c}\text { Nilgün et al., } \\
2020\end{array}$ \\
\hline $\begin{array}{c}\text { Konoplyana } \\
\text { Nasoloda } \\
\text { (Hemp } \\
\text { Delight) } \\
\text { cupcake }\end{array}$ & $\begin{array}{l}34 \% \text { of hemp } \\
\text { flour }\end{array}$ & $\begin{array}{l}\text { Increased nutritional value of finished } \\
\text { products. High organoleptic quality } \\
\text { indicators. }\end{array}$ & $\begin{array}{c}\text { Tkachenko, } \\
2018 ; 2020\end{array}$ \\
\hline $\begin{array}{c}\text { Semi- } \\
\text { finished } \\
\text { minced } \\
\text { meat } \\
\text { products }\end{array}$ & $\begin{array}{l}10 \% \text { of hemp } \\
\text { flour }\end{array}$ & $\begin{array}{l}\text { Increased content of lipids (by 2.2\%), } \\
\text { magnesium (2.4 times) and iron } \\
\text { (1.5 times) }\end{array}$ & $\begin{array}{c}\text { Perekhodova } \\
\text { et al., 2017 }\end{array}$ \\
\hline $\begin{array}{c}\text { Chopped } \\
\text { beef liver } \\
\text { products }\end{array}$ & $\begin{array}{l}15 \% \text { of hemp } \\
\text { flour and } \\
\text { emulsified }\end{array}$ & $\begin{array}{l}\text { Increased water-binding and water- } \\
\text { holding capacity of the product. } \\
\text { Improved fat absorbing, emulsifying } \\
\text { capacity and emulsion stability. }\end{array}$ & $\begin{array}{c}\text { Stoporeva et } \\
\text { al., 2018 }\end{array}$ \\
\hline $\begin{array}{c}\text { Liver pate } \\
\text { hemp oil hemp }\end{array}$ & $\begin{array}{l}\text { Increased fat content and nutritional } \\
\text { value of the product. Improved fatty } \\
\text { acid composition and sensory properties } \\
\text { (hardness, softness and stickiness). }\end{array}$ & $\begin{array}{c}\text { Zając et al., } \\
2018\end{array}$ \\
\hline seeds & $\begin{array}{l}\text { Increased prebiotic activity. The } \\
\text { content of biologically active } \\
\text { compounds is increased due to the } \\
\text { inhibited enteropathogen growth and } \\
\text { high levels of acetate, propionate and } \\
\text { butyrate produced during fermentation. }\end{array}$ & $\begin{array}{c}\text { Nissen et al., } \\
2020\end{array}$ \\
\hline
\end{tabular}

In addition to the foods listed in Table 12, hemp seeds are also used in the production of hemp oil softgel capsules, hemp gummies (Canada), roasted hemp seeds with sea salt, hemp jelly beans, energy drinks, hemp tea, hemp chewing gums, hemp honey, coffee beans and hemp kernel (USA), hemp lager beer, hemp protein bars (UK), hemp candies, hemp chocolate and hemp pads (Netherlands) (Sova et al., 2020).

It is essential that the technology of composite food products provide antimicrobial and antioxidant properties throughout the guaranteed shelf life (Oseyko et al., 2019).

Bartkiene with co-authors (2020) proposes fermentation with Pediococcus acidilactici, P. pentosaceus, Lactobacillus casei and L. uvarum strains, as well as ultrasonic treatment of hemp kernel paste. It includes an assessment of the content of biogenic amines and antimicrobial properties of the derivative products. Combined fermentation and ultrasonic treatment helps lower the total bacteria count in the hemp kernel paste. The treated hemp kernel was found to be rich in biogenic amines, $639.87 \mathrm{mg} / \mathrm{kg}$. Pure lactic acid bacteria showed a reduction in a broad spectrum of pathogens. However, the hemp kernel paste exhibited a very low antimicrobial activity and formulated emulsion did not exhibit any antimicrobial properties. Treatment with selected LAB can be recommended for preparation of stable emulsions, and the most acceptable beverages can be obtained using L. uvarum strain.

Frassinetti and co-authors (2018) evaluated the antioxidant effect of hemp seeds and sprouts after 3 and 5 days of germination. Total polyphenols, flavonoids and flavonols content expressed on a dry basis were highest in sprouts. A number of analyses including 
cellular antioxidant activity in red blood cells and hemolysis test showed a higher antioxidant activity in sprouts than in seeds. Main polyphenol (caffeoyltyramine) was identified in hemp seeds and of $\omega-6$ (linoleic acid) was identified in sprouts. Therefore, hemp seeds and sprouts can have beneficial effects on human body and should be investigated as a potential functional food.

Siano with co-authors (2019) determined chemical and biochemical characteristics including phytosterol composition, total phenolics, antioxidant activity, and content of macro- and microelements of edible hemp resources such as seeds, oil, and flour. Hemp seeds, flour, and oil contained $767 \pm 41,744 \pm 29$, and $21 \pm 5 \mathrm{mg} \mathrm{GAE} / \mathrm{kg}$ of total polyphenols, respectively. The antioxidant potential of hemp flour and seeds was higher than that of oil. $\mathrm{K}$ and $\mathrm{Mg}$ were the most abundant macroelements, particularly in flour, 5064.45 and $2310.54 \mathrm{mg} / \mathrm{kg}$, respectively.

\section{Conclusion}

Hemp seeds and their derivative products are still insufficiently used in food technologies such as cereals, pasta, confectionery, food concentrate, meat and dairy and fermentation. In the short term, the theoretical, scientific and practical insights presented in this review should be used in integrated solutions for the processing of environmentally sound industrial and medical hemp seeds.

It is essential that further research be conducted on the use of drugs to regulate the antimicrobial and antioxidant properties of functional, dietary and specialty products is of paramount importance.

\section{References}

Abdollahi M., Sefidkon F., Calagari M., Mousavi A., Mahomoodally M.F. (2020), A comparative study of seed yield and oil composition of four cultivars of hemp (Cannabis sativa L.) grown from three regions in northern Iran, Industrial Crops and Products, 152, 112397.

Abuzaytoun R., Shahidi F. (2006), Oxidative stability of flax and hemp oils, Journal of the American Oil Chemists 'Society, 83(10), pp. 855-861.

Aladić K., Jarni K., Barbir T., Vidović S., Vladić J., Biliće M., Jokić S. (2015), Supercritical $\mathrm{CO}_{2}$ extraction of hemp (Cannabis sativa L.) seed oil, Industrial Crops and Products, 76, pp. $472-478$.

Aladić K., Jokić S., Moslavac T., Tomas S., Vidović S., Vladić J., Šubarić D. (2014), Cold pressing and supercritical $\mathrm{CO}_{2}$ extraction of hemp (Cannabis sativa) seed oil, Chemical and Biochemical Engineering Quarterly, 28(4), pp. 481-490.

Anwar F., Latif S., Ashraf M. (2006), Analytical characterization of hemp (Cannabis sativa) seed oil from different agro-ecological zones of Pakistan, Journal of the American Oil Chemists Society, 83(4), pp. 323-329.

Babiker E., Uslu N., Al F., Isam J. (2021), Effect of roasting on antioxidative properties, polyphenol profile and fatty acids composition of hemp (Cannabis sativa L.) seeds, Elsevier Ltd, 139, 110537.

Bădărău Carmen L., Apostol L., Mihăilă L. (2018), Effects of hemp flour, seeds and oil additions on bread quality, Journal of Engineering Research and Application, 8(5), pp. 73-78.

Baibekov R.F., Belopukhov S.L., Dmitrevskaia I.I., Dmitriev L.B. (2019), Sravnitelnaia kharakteristika sostava zhirnykh kislot v lipidakh masel iz semian tekhnicheskikh kultur, Dostizhenie nauki i tekhniki APK, 6(33), pp. 62-65. 
Bartkiene E., Zokaityte E., Lele V., Sakiene V., Zavistanaviciute P. (2020), Technology and characterisation of whole hemp seed beverages prepared from ultrasonicated and fermented whole seed paste, Food Science andTechnology, 55(1), pp. 406-419.

Bazhai-Zhezherun S.A., Molodid T.I. (2020), Pokaznyky yakosti khliba, zbahachenoho produktamy pereroblennia konopel, Naukovi zdobutky molodi - vyrishenniu problem kharchuvannia liudstva u XXI stolitti: materialy mizhnarodnoi naukovoi konferentsii molodykh uchenykh, aspirantiv i studentiv, 1, pp. 40.

Cerino P., Buonerba C., Cannazza G., D'Auria J., Ottoni E., Fulgione A., Di Stasio A., Pierri B., Gallo A. (2020), A review of hemp as food and nutritional supplement, Cannabis and Cannabinoid Research, 6(1), pp. 19-27.

Cherney J., Small E. (2016), Industrial hemp in North America: Production, politics and potential, Agronomy, 6(4), 6040058.

Crimaldi M., Faugno, S., Sannino, M., Ardito, L. (2017), Optimization of hemp seeds (Canapa Sativa L.) oil mechanical extraction, Chemical Engineering Transactions, 58, pp. 373-378.

Crini G., Lichtfouse E., Chanet G., Morin-Crini N. (2020), Traditional and new applications of hemp, Sustainable Agriculture, 42, pp 37-87.

Da Porto C., Decorti D., Tubaro F. (2012), Fatty acid composition and oxidation stability of hemp (Cannabis sativa L.) seed oil extracted by supercritical carbon dioxide, Industrial Crops and Products, 36(1), pp. 401-404.

Da Porto C., Natolino A., Decorti D. (2015), Effect of ultrasound pre-treatment of hemp (Cannabis sativa L.) seed on supercritical $\mathrm{CO}_{2}$ extraction of oil, Journal of Food Science and Technology, 52, pp. 1748-1753.

Da Porto C., Voinovich D., Decorti D., Natolino A. (2012), Response surface optimization of hemp seed (Cannabis sativa L.) oil yield and oxidation stability by supercritical carbon dioxide extraction, The Journal of Supercritical Fluids, 68, pp. 45-51.

Dapčević-Hadnađev T., Hadnađev M., Dizdar M., Jovanović-Lješković N. (2020), Functional and bioactive properties of hemp proteins, Sustainable Agriculture Reviews, 42, pp 239-263.

Della Rocca G., Di Salvo A. (2020), Hemp in veterinary medicine: from feed to drug, Frontiers in Veterinary Science, 7, pp. 1-11.

Devi V., Khanam S. (2019), Comparative study of different extraction processes for hemp (Cannabis sativa) seed oil considering physical, chemical and industrial-scale economic aspects, Journal of Cleaner Production, 207, pp. 645-657.

Esmaeilzadeh Kenari R., Dehghan B. (2020), Optimization of ultrasound-assisted solvent extraction of hemp (Cannabis sativa L.) seed oil using RSM: Evaluation of oxidative stability and physicochemical properties of oil, Food Science \& Nutrition, 8(9), pp. 49764986.

Falendysh N.O., Zinchenko I.M., Blazhenko M.S. (2019), Osoblyvosti vyrobnytstva orhanichnoho khliba z vykorystanniam konoplianoho boroshna, Kharchova promyslovist, 25, pp. 7-13.

Farinon B., Molinari R., Costantini L., Merendino N. (2020), The Seed of industrial hemp (Cannabis sativa L.): Nutritional quality and potential functionality for human health and nutrition, Nutrients, 12, pp. 1935-1994.

Fike J. (2016), Industrial hemp: Renewed opportunities for an ancient crop, Critical Reviews in Plant Sciences, 35, pp. 406-424.

Fountoulakis M., Lahm H.W. (2008), Hydrolysis and amino acid composition of proteins, Journal of Chromatography A, 826(2), pp. 109-134.

Frassinetti S., Moccia E., Caltavuturo L., Gabriele M. (2018), Nutraceutical potential of hemp (Cannabis sativa L.) seeds and sprouts, Food Chemistry, 262(1), pp. 56-66.

Girgih, A.T., Udenigwe C.C., Aluko, R.E. (2013), Reverse-phase HPLC separation of hemp seed (Cannabis sativa L.) protein, Plant Foods and Human Nutrition, 68, pp. 39-46. 
Grigorev S.V., Shelenga T.V., Illarionova K.V. (2019), Masla konopli i khlopchatnika obraztsov kollektsii VIR kak istochnik funktsionalnykh pishchevykh ingredientov, Trudy po prikladnoi botanike, genetike i selektsii, 180(2), pp. 38-43.

Hamidioglu1 I., Salaseviciene A., Zaborskiene G. (2019), Effects of natural herbal extracts on hemp (Cannabis Sativa L.) oil quality indicators, Foods and Raw Materials, 2019, 7(1), pp. $35-41$.

Holia A., Kyrpichenkova O. (2018), Rozrobka pechyva funktsionalnoho pryznachennia z vykorystanniam shrotu nasinnia konopli, Naukovi zdobutky molodi - vyrishenniu problem kharchuvannia liudstva u KhKhI stolitti: tezy dopovidei 84-yi Mizhnarodnoi naukovoi konferentsii molodykh vchenykh, aspirantiv i studentiv, 3, pp. 411.

Iorgacheva K., Sokolova N. (2020), The potential of flour from solvent extraction hemp oilcake as an ingredient of low moisture bakery products, Food Science and Technology, 14(3), pp. 44-51.

Iurchenko E.N., Kaniuka E.Iu. (2019), Zhirnokislotnyi sostav rastitelnykh masel, Naukovii zhurnal «L'OGOL. Mistetstvo naukovoï dumki», 2, pp. 67-69.

Ivanovs S., Adamovichs A., Rutsinsh A. (2017), Rasshirenie vozmozhnostei ispolzovaniia produktsii industrialnoi konopli, Tekhnologii i tekhnicheskie sredstva mekhanizirovannogo proizvodstva produktsii rastenievodstva i zhivotnovodstva, pp. 118-125.

Jagelaviciute J., Cizeikiene D. (2021), The influence of non-traditional sourdough made with quinoa, hemp and chia flour on the characteristics of gluten-free maize/rice bread, $L W T, 137$, 110457.

James D., House J., Neufeld J., Leson G. (2010), Evaluating the quality of protein from hemp seed (Cannabis sativa L.) products through the use of the protein digestibility-corrected amino acid score method, Journal of Agricultural and Food Chemistry, 58(22), pp. 118-125.

Karus M., Vogt D. (2004), European hemp industry: Cultivation, processing and product lines, Euphytica, 140, pp. 7-14.

Klevtsov K.M. (2015), Fizyko-tekhnolohichni vlastyvosti i khimichnyi sklad nasinnia lonu ta konopel, Visnyk Khersonskoho natsionalnoho tekhnichnoho universytetu, 4(55), pp. 104 110.

Klir Ž., Novoselec J., Antunović Z. (2019), An overview on the use of hemp (Cannabis sativa L.) in animal nutrition, Poljoprivreda/Agriculture, 25, pp. 52-61.

Kolodziejczyk L., Ozimek P., Kozłowska J. (2012), The application of flax and hemp seeds in food, animal feed and cosmetics production, Handbook of Natural Fibres, 2, pp. 329-366.

Korus Ja., Witczak M., Ziobro R., Juszczak L. (2017), Hemp (Cannabis sativa subsp. sativa) flour and protein preparation as natural nutrients and structure forming agents in starch based gluten-free bread, $L W T, 84$, pp. 143-150.

Kriese U., Schumann E., Weber W.E., Beyer M., Brühl L., Matthäus (2005), Oil content, tocopherol composition and fatty acid patterns of the seeds of 51 Cannabis sativa L. genotypes, Euphytica, 137, pp. 339-351.

Laiko I.M., Virovets V.G., Mishchenko S.V., Vereshchagin I.V. (2014), Obosnovanie sozdaniia samoopylennykh linii nenarkoticheskoi konopli dlia selektsii na povyshenie maslichnosti, Maslichnye kultury. Nauchno-tekhnicheskii biulleten Vserossiiskogo nauchno issledovatelskogo instituta maslichnykh kultur, 1, pp. 27-31.

Lamotkin S.A., Ilina G.N. (2016), Issledovanie stabilnosti rastitelnykh masel k okisleniiu kislorodom vozdukha pri sozdanii produktsii so sbalansirovannym zhirnokislotnym sostavom, Innovatsionnye tekhnologii v pishchevoi promyshlennosti, pp. 99-101.

Lan Y., Zha F., Peckrul A., Hanson B., Johnson B., Rao J., Chen B. (2019), Genotype and environmental effects on yielding ability and seed chemical composition of industrial hemp (Cannabis sativa L.) varieties grown in North Dakota, Journal of the American Oil Chemists Society, 96(12), pp.1417-1425. 
Latif S., Anwar F. (2009), Physicochemical studies of hemp (Cannabis sativa) seed oil using enzyme-assisted cold-pressing, European Journal of Lipid Science and Technology, 111(10), pp.1042-1048.

Leizer C., Ribnicky D., Poulev A., Dushenkov S., Raskin I. (2000), The Composition of Hemp Seed Oil and Its Potential as an Important Source of Nutrition, Journal of Nutraceuticals, Functional \& Medical Foods, pp. 35-53.

Leonard W., Zhang P., Ying D., Fang Zh. (2020), Hempseed in food industry: Nutritional value, health benefits, and industrial applications, Comprehensive reviews in food science and food safety, 19(1), pp. 282-308.

Leson G. (2006), Hemp Foods in North America, Journal of Industrial Hemp, 11(1), pp. 87-93.

Liang J., Aachary A.A, Hydamaka A., Eskin M., Esk P., Thiyam-Holländer U. (2018), Reduction of chlorophyll in cold-pressed hemp (Cannabis sativa) Seed oil by ultrasonic bleaching and enhancement of oxidative stability, European Journal of Lipid Science and Technology, 120(4), pp. 325-334.

Liang J., Aachary A.A., Thiyam-Holländer U. (2015), Hemp seed oil: Minor components and oil quality, Lipid Technology, 27(10), pp. 231-233.

Lukianenko P.V., Riabchenko O.P. (2009), Vyznachennia vplyvu osnovnykh faktoriv na tryvalist sushinnia ta pokaznyky yakosti nasinnia konopel, zibranoho zernozbyralnym kombainom, Visnyk Sumskoho natsionalnoho ahrarnoho universytet, 1(20), pp. 125-130.

Lukin A., Bitiutskikh K. (2017), Investigation on the use of hemp flour in cookie production, Bulgarian Journal of Agricultural Science, 23(4), pp. 664-667.

Malomo S.A., Rong H., Aluko R.E. (2014), Structural and functional properties of hemp seed protein products, Journal of Food Science, 79(8), pp. 1512-1521.

Mamone G., Picariello G., Ramondo A., Nicolai M.A., Ferranti P. (2019), Production, digestibility and allergenicity of hemp (Cannabis sativa L.) protein isolates, Food Research International, 115, pp. 562-571.

Metwally S.P., Ura D.J., Krysiak Z., Kaniuk L.K., Szewczyk P., Stachewicz U. (2021), Electrospun PCL patches with controlled fiber morphology and mechanical performance for skin moisturization via long-term release of hemp oil for atopic dermatitis, Membranes, 11(1), pp. 26.

Mihoc M., Pop G., Alexa E., Dem D., Militaru A. (2013), Microelements distribution in whole hempseeds (Cannabis Sativa L.) and in their fractions, Revista De Chimie, 64(7), pp. 776780.

Mikulcova V., Kasparkova V., Humpolicek P., Bunkova L. (2017), Formulation, characterization and properties of hemp seed oil and its emulsions, Molecules, 22, pp. 1-13.

Mikulec A., Kowalski S., Sabat R. (2019), Hemp flour as a valuable component for enriching physicochemical and antioxidant properties of wheat bread, $L W T, 102$, pp. 164-172.

Mishchenko S.V. (2013), Zalezhnist skhozhosti nasinnia samozapylenykh linii konopel vid pokolinnia i tryvalosti zberihannia, Visnyk Poltavskoi derzhavnoi ahrarnoi akademii, 2, pp. 36-39.

Moczkowska M., Karp S., Horbanczuk O.K., Hanula M., Wyrwisz J., Kurek M. A. (2020), Effect of rosemary extract addition on oxidative stability and quality of hemp seed oil, Food and Bioproducts Processing, 124, pp. 33-47.

Montserrat-de la Paz S., Marín-Aguilar F., García-Giménez M.D., Fernández-Arche M.A. (2014), Hemp (Cannabis sativa L.) seed oil: Analytical and phytochemical characterization of the unsaponifiable fraction, Journal of Agricultural and Food Chemistry, 62(5), pp. 1105-1110.

Morar M.V., Dragan K., Bele C., Matea C., Tarta I., Suharovschi R., Semeniuc C. (2010), Researches regarding the processing of the hemp seed by cold pressing, Bulletin of University of Agricultural Sciences and Veterinary Medicine Cluj-Napoca, Agriculture, 67(2), pp. 284-290. 
Nataša R., Derić Olja M., Todorić M., Rošul D., Sunčica D. (2020), Influence of different chemical agents and storage conditions on the microbiological content of industrial hemp (Cannabis sativa L.) seeds, Food and Feed Research, 47(2), pp. 159-168.

Nilgün E., Mine A. (2020), Antioxidant and physicochemical properties of cookies containing raw and roasted hemp flour, Acta Scientiarum Polonorum Technologia Alimentaria, 19(2), pp. 177-184.

Nissen L., Carlo E., Gianotti A. (2020), Prebiotic potential of hemp blended drinks fermented by probiotics. Food Research International, 131, pp. 125-131.

Noelia M., Rodriguez-Martin N.M., Toscano R., Villanueva A., Pedroche J. (2019), Neuroprotective protein hydrolysates from hemp (Cannabis sativa L.) seeds, Food Function, 10, pp. 112-120.

Orhan İ., Küsmenoğlu Ş., Şener B. (2000), GC-MS analysis of the seed oil of Cannabis sativa L. cultivated in Turkey, Gazi Universitesi Eczacilik Fakultesi Dergisi, 17, pp. 79-81.

Oseiko M.I. (2006), Tekhnolohiia roslynnykh olii, VV «Varta», Kyiv.

Oseyko M., Romanovska T., Shevchyk V. (2020), Justification of the amino acid composition of sunflower proteins for dietary and functional products, Ukrainian Food Journal, 9(2), pp. 394-403.

Oseyko M., Shevchyk V., Pokryshko O. (2019), Antimicrobial and antifungal activity of model drugs on the basis of food plant extracts in the systemic concept of health, Ukrainian Journal of Food Science, 7(1), pp. 70-82.

Oseyko M., Sova N., Lutsenko M., Kalyna V. (2019), Chemical aspects of the composition of industrial hemp seed products, Ukrainian Food Journal, 8(3), pp. 544-559.

Oseyko M., Sova N., Petrachenko D., Mykolenko S. (2020), Technological and chemical aspects of storage and complex processing of industrial hemp seeds, Ukrainian Food Journal, 9(3), pp. 545-560.

Parihar S.S., Dadlani M., Lal S.K., Tonapi V.A., Nautiyal P.C., Sudipta B. (2014), Effect of seed moisture content and storage temperature on seed longevity of hemp (Cannabis sativa), Indian Journal of Agricultural Sciences, 84(11), pp. 1303-1309.

Perekhodova E.A., Naumova N.L., Lukin A.A. (2017), Ispolzovanie konoplianoi muki v proizvodstve miasnykh rublennykh polufabrikatov, Tekhnologiia $i$ tovarovedenie innovatsionnykh pishchevykh produktov, 2017, 4(45), pp. 43-46.

Petrachenko D.O., Koropchenko S.P. (2019), Doslidzhennia konstruktsii mekhanizmu dlia obrushuvannia nasinnia promyslovykh konopel, Vcheni zapysky TNU imeni $V$. I. Vernadskoho. Seriia: tekhnichni nauky, 30(69), 167-171.

Pojić M., Dapčević Hadnađev T., Hadnađev M., Rakita S., Brlek T. (2015), Bread supplementation with hemp seed cake: A by-product of hemp oil processing, Journal of Food Quality, 38(6), pp. 431-440.

Pojić M., Hadnađev M., Hadnađev-Dapčević T., Mišan A., Sakač M., Šarić B. (2014), Testenina obogaćena konopljinim brašnom - novi testeničarski proizvod, Hrana i ishrana, 55(2), pp. $37-42$.

Pojić M., Mišan A., Sakač M., Dapčević Hadnađev T., Šarić B., Milovanović I., Hadnađev M. (2014), Characterization of byproducts originating from hemp oil processing, Journal of Agriculture Food Chemistry, 62(51), pp. 12436-12442.

Potin F., Saurel R. (2020), Hemp seed as a source of food proteins, Sustainable Agriculture Reviews, 42, pp 265-294.

Radočaj O., Dimić E., Tsao R. (2014), Effects of hemp (Cannabis sativa L.) seed oil press-cake and decaffeinated green tea leaves (Camellia sinensis) on functional characteristics of gluten-free crackers, Journal of Food Science, 79(3), pp. 318-325.

Raikos V., Duthie G., Ranawana V. (2015), Denaturation and oxidative stability of hemp seed (Cannabis sativa L.) Protein isolate as affected by heat treatment, Plant Foods for Human Nutrition, 70, pp. 304-309. 
Raikos V., Konstantinidi V., Duthie G. (2015), Processing and storage effects on the oxidative stability of hemp (Cannabis sativa L.) oil-in-water emulsions, Food Science and Technology, 50(10), pp. 2316-2322.

Ruban A., Hrivna L., Lizet Hernandez Kong J. (2016), The use of hemp and color wheat flour as baking ingredients, MENDELNET, 23, pp. 639-644.

Sacilik K., Öztürk R., Keskin R. (2003), Some physical properties of hemp seed, Biosystems Engineering, 86(2), pp. 191-198.

Samofalova L.A., Berezina N.A. (2004), Povyshenie kachestva rzhano-pshenichnogo khleba putem vneseniia konoplianoi dobavki, Izvestiia vuzov. Pishchevaia tekhnologiia, 4, pp. 3133.

Sapino S., Carlotti M.E., Peira E., Gallarate M. (2005), Hemp-seed and olive oils: Their stability against oxidation and use in $\mathrm{O} / \mathrm{W}$ emulsions, International Journal of Cosmetic Science, 27(6), pp. 355-355.

Schluttenhofer C., Yuan L. (2017), Challenges towards revitalizing hemp: A multifaceted crop, Trends in Plant Science, 22(11), pp. 917-929.

Serkov V.A., Danilov M.V., Belousov R.O., Aleksandrova M.R., Davydova O.K. (2020), Zhirnokislotnyi sostav masla semian novogo sorta konopli posevnoi Milena, Mezhdunarodnyi selskokhoziaistvennyi zhurnal, 6(378), pp. 101-103.

Serkov V.A., Zelenina O.N., Smirnov A.A., Pluzhnikova I.I. (2011), Vozdelyvanie srednerusskoi odnodomnoi konopli v lesostepi srednego Povolzhia, Gosudarstvennoe nauchnoe uchrezhdenie Penzenskii nauchno-issledovatelskii institut selskogo khoziaistva Rosselkhozakademii, pp. 40.

Shashkarov L.G., Dimitriev V.L., Chernov A.V. (2016), Perspektivy ispolzovaniia novykh bezgashishnykh odnodomnykh sortov konopli dlia organizatsii proizvodstva bio- i nanoproduktov, Vestnik Kazanskogo gosudarstvennogo agrarnogo universiteta, 3(41), pp. $58-62$.

Shelenga T.V., Grigorev S.V., Baturin V.S., Sarana Iu.V. (2010), Biokhimicheskaia kharakteristika semian konopli (Cannabis Sativa L.) iz razlichnykh regionov Rossii, Doklady Rossiiskoi akademii selskokhoziaistvennykh nauk, 4, pp. 22-32.

Shelenga T.V., Grigorev S.V., Illarionova K.V. (2012), Biokhimicheskaia kharakteristika semian i volokna obraztsov konopli (Cannabis Sativa L.) iz kollektsii VIR im. N.I. Vavilova, Trudy po prikladnoi botanike, genetike i selektsii, 170, pp. 212-219.

Shen P., Gao Z., Xu M., Ohm J.-B., Rao J., Chen B. (2020), The impact of hempseed dehulling on chemical composition, structure properties and aromatic profile of hemp protein isolate, Food Hydrocolloids, 106, 105889.

Shewry P.R., Napier J.A., Tatham A.S. (2000), Seed storage proteins: Structures and biosynthesis, The Plant Cell, 7, pp. 945-956.

Siano F., Moccia S., Picariello G., Luigi Russo G., Sorrentino G., Di Stasio M., La Cara F., Grazia Volpe M. (2019), Comparative study of chemical, biochemical characteristic and ATRFTIR analysis of seeds, oil and flour of the edible fedora cultivar hemp (Cannabis sativa L.), Molecules, 24(83), pp. 1-13.

Silversides F.G., LefranÇois M.R. (2005), The effect of feeding hemp seed meal to laying hens, British Poultry Science, 46(2), pp. 231-235.

Small E., Brookes B. (2012), Temperature and moisture content for storage maintenance of germination capacity of seeds of industrial hemp, marijuana, and ditchweed forms of Cannabis sativa, Journal of Natural Fibers, 9(4), pp. 240-255.

Sova N., Lutsenko M., Korchmaryova A., Andrusevych K. (2018), Research of physical and chemical parameters of oil obtained from organic and conversion hemp seeds varieties «Hliana», Ukrainian Food Journal, 7(2), pp. 244-252.

Sova N.A., Chornei K.A., Kovalenko N.V. (2020), Analiz suchasnoho asortymentu konoplianykh kharchovykh produktiv, "Aktualni Problemy u Sferi Torhivli ta Tovaroznavstva», Materialy 
mizhnarodnoi naukovo-praktychnoi Internet-konferentsii, 16-18 veresnia, 2020, Kherson, Ukraina, pp. 165-167.

Sova N.A., Chornei K.A., Kovalenko N.V. (2021), Osoblyvosti skladu promizhnykh produktiv, oderzhanykh pry vyrobnytstvi konoplianoho yadra, Oliini kultury: sohodennia ta perspektyvy. Zbirnyk tez Mizhnarodnoi naukovoi internet-konferentsii, IOK NAAN, 31 bereznia, 2021, Zaporizhzhia, Ukraina, pp. 116-117.

Sova N.A., Lutsenko M.V., Yefimov V.H., Kurhalin S.M. (2018), Kharakterystyka sypkykh konoplianykh produktiv, Visnyk Natsionalnoho tekhnichnoho universytetu «KhPI». Seriia: Novi rishennia $v$ suchasnykh tekhnolohiiakh, 45(1321), pp. 207-213.

Sova N.A., Voitanishek D.I., Lutsenko M.V., Petrachenko D.O. (2019), Osoblyvosti pisliazbyralnoi obrobky nasinnia promyslovykh konopel, Visnyk Khersonskoho natsionalnoho tekhnichnoho universytetu, 1(68), pp. 129-135.

Stefan H.M., Gorissen S., Crombag J., Senden J. (2018), Protein content and amino acid composition of commercially available plant-based protein isolates, Springer Open Choice, 50(12). pp. 1685-1695.

Stoporeva T.A., Vaitanis M.A., Novoselov S.V. (2018), Issledovanie farshevykh sistem iz goviazhei pecheni s dobavleniem konoplianoi muki, Polzunovkii vestnik, 2, pp. 85 - 90.

Subratti A., Lorale J., Lalgee, Nigel K., Jalsa (2019), Liquified dimethyl ether (DME): A green solvent for the extraction of hemp (Cannabis sativa L.) seed oil, Sustainable Chemistry and Pharmacy, 12, pp. 1-6.

Sukhorada T.I., Proidak M.N., Gerasimova A.S., Shabelnyi M.M. (2009), Novyi sort konopli maslichnogo napravleniia Omegadar, Maslichnye kultury. Nauchno-tekhnicheskii biulleten Vserossiiskogo nauchno issledovatelskogo instituta maslichnykh kultur, 1(140), pp. 147150.

Suriyonga S., Krittigamasa N., Pinmaneeb S., Punyalueb A., Vearasilp S. (2015), Influence of storage conditions on change of hemp seed quality, Agriculture and Agricultural Science Procedia, 5, pp. 170-176.

Teh S.S., Din A. E., Bekhit A., Carne A., Birch J. (2016), Antioxidant and ACE-inhibitory activities of hemp (Cannabis sativa L.) protein hydrolysates produced by the proteases AFP, HT, Pro-G, actinidin and zingibain, Food Chemistry, 203, pp. 199-206.

Tkachenko A.S. (2018), Vyvchennia spozhyvchykh vlastyvostei keksiv, rozroblenykh na osnovi orhanichnoi syrovyny, Naukovyi visnyk Poltavskoho universytetu ekonomiky i torhivli, 1(85), pp. 135-144.

Tkachenko A.S. (2020), Naukove obgruntuvannia rozroblennia keksiv z orhanichnoi syrovyny z pidvyshchenym mineralnym skladom, Visnyk Lvivskoho torhovelno-ekonomichnoho universytetu. Tekhnichni nauky, 23, pp. 110-115.

Valizadehderakhshan M., Shahbazi A., Kazem-Rostami M., Scott Todd M., Bhowmik A., Wang L. (2021), Extraction of cannabinoids from Cannabis sativa L. (Hemp) - Review, Agriculture, 11(384), pp. 1-24.

Virovets V.G., Vereshchagin I.V. (2014), Perspektivnyi iskhodnyi material na maslichnost v selektsii nenarkoticheskoi posevnoi konopli, Vestnik Altaiskogo gosudarstvennogo agrarnogo universiteta, 1(111), pp. 19-23.

Vonapartis E., Aubin M.-P., Seguin Ph., F. Mustafa A., Charrona J.-B. (2015), Seed composition of ten industrial hemp cultivars approved for production in Canada, Journal of Food Composition and Analysis, 39, pp. 8-12.

Vyrovets V.H., Laiko I.M., Vereshchahin I.V., Tymchuk S.M., Pozdniakov V.V. (2011), Perspektyvy selektsii na optymizatsiiu zhyrnokyslotnoho skladu olii suchasnykh sortiv nenarkotychnykh konopel, Selektsiia i nasinnytstvo, 100, pp. 247-254.

Wang X.S., Tang C.H., Yang X.Q., Gao W.R. (2018), Nutritional assessment of Hemp (Cannabis sativa L.) Proteins, Journal of agricultural and food, 132, pp. 115-126. 
Williams D.W. (2019), Hemp Grain, Industrial Hemp as a Modern Commodity Crop, Agriculture \& Ecology, Madison.

Xu Yo., Li Ju., Zhao J., Wang W. (2020), Hempseed as a nutritious and healthy human food or animal feed source: A review. Food Science and Technology, 107, pp. 11-18.

Yin S.W., Tang C.H., Wen Q.B., Yang X.Q. (2009), Functional and structural properties and in vitro digestibility of acylated hemp (Cannabis sativa L.) protein isolates, Food Science and Technology, 44(12), pp. 2653-2661.

Yufriakova K.M., Bessarab T.V., Melnyk O.Yu. (2020), Vykorystannia produktiv pererobky konopli u vyrobnytstvi khlibobulochnykh vyrobiv, Aktualnye nauchnye issledovaniia $v$ sovremennom mire, 10(66), pp. 135-140.

Zając M., Świątek R. (2018), The effect of hemp seed and linseed addition on the quality of liver pâtés, Acta Scientiarum Polonorum Technologia Alimentaria, 17(2), pp. 169-176.

Zanoni C., Aiello G., Arnoldi A., Lammi C. (2017), Hempseed peptides exert hypocholesterolemic effects with a statin-like mechanism, Journal of Agricultural and Food Chemistry, 65, pp. 8829-8838. 